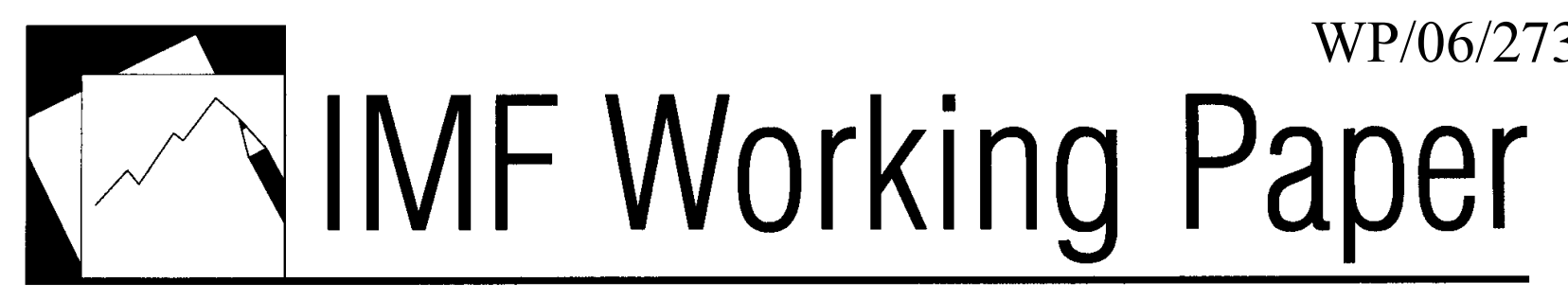

\title{
Rethinking the Governance of the International Monetary Fund
}

Abbas Mirakhor and Iqbal Zaidi 



\title{
IMF Working Paper
}

Office of the Executive Director for the Islamic Republic of Afghanistan, Algeria, Ghana, the Islamic Republic of Iran, Morocco, Pakistan, and Tunisia

\section{Rethinking the Governance of the International Monetary Fund}

Prepared by Abbas Mirakhor and Iqbal Zaidi

December 2006

\begin{abstract}
This Working Paper should not be reported as representing the views of the IMF. The views expressed in this Working Paper are those of the author(s) and do not necessarily represent those of the IMF or IMF policy. Working Papers describe research in progress by the author(s) and are published to elicit comments and to further debate.
\end{abstract}

This paper attempts to set out the principal issues that need to be resolved in formulating a proposal for quotas and voice reform in the IMF that could command broad support. Following John Rawls, we argue that "justice is the first virtue of social institutions," and we use his theory of justice to provide a method for understanding what should be the case, in the context of voice and voting shares, before international institutions, such as the IMF, are to be justifiable to their members. The implementation of this process suggests, among other things, that a major revision of the quota formulas is long overdue, and leaving this unaddressed raises serious questions regarding the IMF's governance which could develop into a core mission risk and jeopardize the relevance of the institution.

JEL Classification Numbers: F02, F33, F53

Keywords: Governance, International Monetary Arrangements and Institutions, International Monetary Fund

Authors’ E-Mail Addresses: amirakhor@imf.org; izaidi@imf.org 


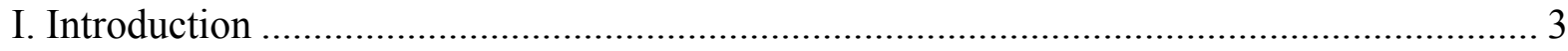

II. Quotas, Voice, and Rawls ............................................................................... 7

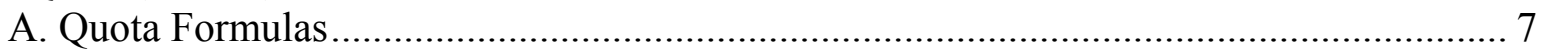

B. Original Bretton Woods Formula Versus Original Position ..................................... 10

III. Rawls's Method ................................................................................................... 14

A. Quota Formula Review Group (QFRG) ........................................................... 14

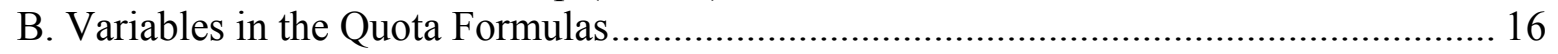

C. Reflective Equilibrium ................................................................................... 18

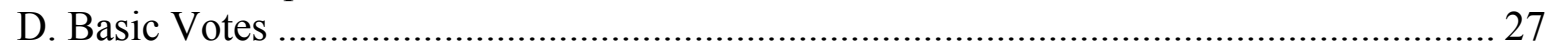

IV. The Way Forward ............................................................................................ 29

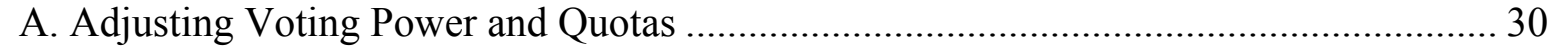

B. Aligning Quotas and Basic Votes with Justice as Fairness....................................... 32

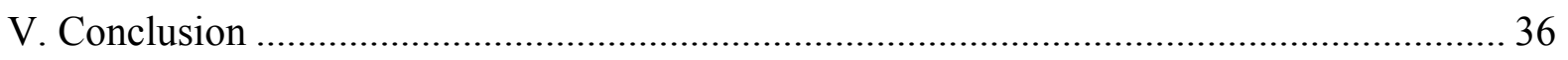

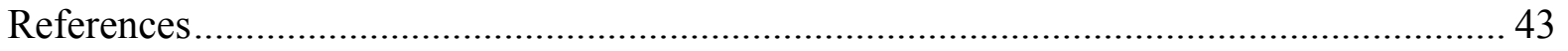

Text Table 1. Basic Votes and Variables for Quota Formulas ........................................... 31

Appendix Table 1. Formulas Used for Quota Calculation: 2006 Update............................ 38 


\section{INTRODUCTION}

Just as national regulation was broadened in the $19^{\text {th }}$ and $20^{\text {th }}$ centuries to protect workers and consumers (e.g., anti-trust legislation, health standards, corporate governance, bank supervision) from the excesses of free markets, there is now a general recognition that globalization needs a regulatory framework in the $21^{\text {st }}$ century that is less fragmented than what exists today, and international financial institutions - in particular, the International Monetary Fund (IMF) — can be expected to have major roles in this area. In fact, the IMF has already taken steps in this direction (e.g., evaluating countries' compliance with international data standards, moving in the direction of setting a new surveillance remit, and launching a multilateral consultation on addressing global imbalances). However, for the IMF to play an important role in global governance, it is essential to enhance its credibility as an international cooperative institution: there is widespread recognition that the quotas (IMF capital shares), voting rights, and voice imbalances have become progressively worse. ${ }^{1}$ The effectiveness of the IMF has been questioned both inside and outside the institution not only because members' quotas have become increasingly out of line with countries' economic weight (measured by GDP) in the global economy, but also because there is a growing recognition that some important aspects of members' economic weight and other variables that should have a bearing on voting rights are not captured in the current quota formulas.

These concerns are reflected in the International Monetary and Financial Committee communiqué of April 22, 2006, which stated that the IMF's effectiveness and credibility as a cooperative institution must be safeguarded and its governance further enhanced, and emphasized the importance of fair voice and representation for all members. The IMF has adopted a two-stage process for quota and voice reform, with initial ad hoc increases for the clearly most underrepresented members in the first stage, and more fundamental reforms in the second stage. ${ }^{2}$ While the specific reform proposals for the second stage are just beginning to be discussed, there is already considerable concern among developing countries that the discussion is being confined to an unduly narrow area, and important issues are not being raised. These concerns are only magnified by the concerted efforts being made in many quarters to validate the traditional approach of basing voting power in the IMF largely on countries' respective weight in the world economy, with the justification being provided in terms of the mandate of the institution. However, representatives from developing countries have rightly pointed out that the IMF mandate is not as narrow as some would have us

\footnotetext{
${ }^{1}$ Quotas are currently calculated according to a member's gross domestic product, current account transactions, and official reserves. The quota largely determines a member's voting power in IMF decisions and is reviewed every five years, with the next review due in 2008 (see Section II).

${ }^{2}$ A two-stage process with an ad hoc increase in the first stage is not consistent with the need for a comprehensive review, and the Finance Minister of India was correct in saying during the IMF-World Bank Annual Meetings in Singapore in October 2006 that "[b]y definition, a comprehensive reallocation of quotas to reinforce legitimacy cannot be achieved by a short-term ad hoc approach." Equally valid is the point that the under-representation of developing countries undermines the credibility and legitimacy of the Bretton Woods Institutions, which hinders effectiveness and relevance of these institutions, as noted in the G-24 communiqué during those meetings.
} 
believe, and history bears this out. Furthermore, even in the discussions on the need to find ways to enhance the representation of developing countries, the discussion seems to be almost entirely directed to the admittedly important, but still only one area of voice reform, namely, the need to arrest the declining role of basic votes since the IMF was established, which has weakened the voice of smaller developing countries. However, the voice reform should mean much more than just ensuring that small countries, whose share in the world economy is small but for whom the IMF provides important policy advice and financing, have adequate opportunities to participate in the governance of the institution. In particular, the IMF also provides policy advice and financing to countries with large populations - and, of course, it has important regulatory and supervisory functions that affect them - and there will remain a "democracy deficit" if these countries are not adequately represented in the governance structure.

These concerns are also not lessened by the fact that the Achilles Heel of the two-stage approach adopted by the IMF is that the formula issue is to be addressed in the second stage, which puts the cart before the horse because it was decided to correct the quotas of some members in the first stage by using the same formulas that are widely regarded as faulty and inadequate. The ad hoc increase in quotas in the first round was supposed to play an important role in improving the distribution of quotas to reflect changes in the weight and role of countries in the world economy. The quota formulas were used to find clearly underrepresented countries, which turned out to be only four (China, Korea, Mexico and Turkey) for ad hoc quota increases. However, it does not require rocket science to know that a wrong metric will give a wrong result. In fact, instead of providing useful information for deciding on the ad hoc increase in the first round, what the calculations confirmed, based on the faulty formulas, was that the use of inappropriate variables (e.g., using market exchange rates rather than purchasing power parity to derive GDP, collinearity amongst the variables, the problem of multiple quota formulas, and the nonlinearities in the quota formula) tended to skew results in the most troublesome ways. ${ }^{3}$

The proponents of the ad hoc increases had argued that the first round of increases would cover only those countries that meet a robust standard of underrepresentedness, but ignored the fact that a robust standard derived from a flawed formula is an oxymoron. It is hard to understand, given the widespread dissatisfaction with the quota formulas, why these formulas were used for deciding on the ad hoc increase in quotas. The preferred approach would have been to look at the problem in an integrated framework, focusing, in particular, on the quota

\footnotetext{
${ }^{3}$ It is disconcerting to note that three of the four countries that received the ad hoc increase in the first round of the quota and voice reform (Korea, Mexico, Turkey) had their quotas calculated using the new formulas, which give a lower weight to GDP than the Bretton Woods formula (see Appendix Table). In other words, the clearly most underrepresented members were supposedly the ones whose economic weight (i.e., GDP) was not adequately reflected in the share of voting power in the IMF, but ironically, for these three countries, it is the openness and external variability metrics that were relatively more important in the determination of the calculated quotas than if the Bretton Woods formula had been used. As discussed in Section II, the Bretton Woods formula has a coefficient of 0.01 in front of the GDP variable, whereas in the new formulas it is lower, ranging from $0.0045-0.0065$.
} 
formulas and basic votes. By resolving or at least making substantial progress on the revamping of the quota formulas in the first step, the IMF would have sent an important signal that its governance reform is not focused on the quota problems of just a handful of countries, but is meant to address the voice imbalances that exist across the membership. After resolving the issue of the quota formula, which is the only way to come up with the correct metric for discussing which countries' quotas are most out of line as well as the broader question of the overall distribution of quotas across regions and across analytical country classifications, the IMF would have put itself in a position to grant significant ad hoc increases to a few members, as well as selective increases that would be distributed across a wide group of countries.

This paper does not focus on the flaws in the two-stage approach to quota reform, but instead takes a forward looking approach and attempts to set out the principal issues that need to be resolved in formulating a proposal for quotas and voice reform that could command broad support. Following John Rawls, we argue that "justice is the first virtue of social institutions," and we think that his theory of justice provides an appropriate method for understanding what should be the case, in the context of voice and voting shares, before international institutions, such as the IMF, are to be justifiable to their members. Our analysis is based on the Rawlsian notion of "justice as fairness" and, at the risk of oversimplification, our conclusion is that justice in the IMF governance structure requires a distribution of voting power that participants accept as the end-result of a fair process. The implementation of this process suggests that a major revision of the quota formulas is long overdue, and leaving this unaddressed raises serious concerns regarding the IMF's governance. Furthermore, there is no legitimate way to view these issues in isolation, and a holistic approach is required, which would entail increasing basic votes sharply-to at least restore its importance at the inception of the IMF - and revamping the quota formulas, with the latter allowing for selective quota increases for a broad group of developing countries. However, we hasten to add that this work should be regarded as advancing possible options for further discussion, and not as constituting a specific proposal. In particular, the ranges given to demand and supply variables, or for treating the democracy and Westphalian deficits, in the quota table in this paper, are for heuristic purposes only and are not meant to be specific recommendations.

The IMF has a complex governance structure in which the constituency system attempts to reconcile the legitimacy of an almost universal membership with efficient decision-making and collegiality of a not-too-large Executive Board (24 Executive Directors). In the constituency system, the five member countries with the largest quotas appoint an Executive Director, while the remaining members elect the remaining Executive Directors. Questions have been raised about the constituency system, particularly the point that the Executive Director cannot split his/her vote even though there are instances in which the countries within the constituency are divided on the issue being considered by the Board; this is especially relevant in those cases in which there are mixed constituencies, industrial and developing countries. Another governance issue has been the debate on converting the International Monetary and Finance Committee (IMFC) into a decision-making council. After long debates, this was turned down in 1999, attributed mainly to the concern that the industrial country members of the council may not show the necessary patience and willingness to work toward consensus decision-making, which is necessary to protect the 
interests of minority groups. Yet another set of questions relates to the simple majority that applies to many decisions and the special majorities of 70 and 85 percent for certain key decisions. The special majorities help to protect sizeable minorities, but the 85 percent majority gives veto power to one country.

The issues raised in the preceding paragraph are just a few of the many outstanding issues in the IMF governance debate, but this paper does not attempt to cover every conceivable area. First, it does not discuss the merits or otherwise of voting majorities, or the efficacy and representation of the constituency system. Nor does it express a view on converting the IMFC into a council. The paper focuses on the quotas and voice debate, which is arguably the overriding issue in the larger governance debate. Second, and at least equally important, the paper does not discuss the question of increasing the independence and accountability of the Executive Board. The Board of Governors is the highest decision-making body of the IMF but the daily business is conducted by a resident Executive Board, which exercises under delegation most of the powers. The main functions of the Executive Board include: approving all policies of the IMF; discussing consultation reports with individual countries, the world economic outlook and the global financial system to carry out its mandate on bilateral and multilateral surveillance; and approving loans provided for adjustment programs and reviewing the implementation of the conditions attached to those programs to decide on whether to disburse the loan tranches. The question of political oversight by national capitals of the business of the IMF has garnered attention from time to time, and in particular, some rules and practices related to the appointment, election, and term duration of Executive Directors have been challenged by some observers from the point of view of strengthening the autonomy and accountability of the Executive Board. These issues are not discussed in the paper not because they are simple and unimportant, but rather because these problems have been extensively analyzed elsewhere and because they are quite distinct from the questions raised in this paper on quotas and voice reform. ${ }^{4}$ Third, it should perhaps be made explicit that the paper is not concerned with other areas, such as the desirability of further enhancing the capacity of Executive Directors' offices representing large numbers of African members and of including more transparent selection procedures for the position of Managing Director. These issues are not discussed not because they are unimportant, but because they are simple. There is no question that the challenges faced by the two African chairs, each of which represents more than 20 countries, are serious. However, this is not an area that requires further deliberations, and it should be implemented expeditiously. The point is that the resources involved for strengthening capacity of African Executive Directors' offices are not substantial in terms of the overall budget of the IMF, and by having these problems linger on, they only serve to confuse the discussion about quotas, basic votes, legitimacy, which are issues of a different kind than some small budgetary matters; in short, a larger budget for an Executive Director's office is no substitute for underrepresentation. On the desirability of including more transparent selection procedures for the position of Managing Director of the IMF, this too should have been done some time ago because there

\footnotetext{
${ }^{4}$ See Kenen (2001), King (2006), Portugal (2003), Truman (2006), Van Houtven (2002) and Woods (1998, 2001) for comprehensive discussions of these issues. See Boughton (2001) for the recent history of IMF finances, pp. 849-874.
} 
really is no debate about it, at least ever since the discussion on the joint draft report of the IMF's Working Group to Review the Process of Selection of the Managing Director and the World Bank Working Group to Review the Process of Selection of the President. In this regard, specific procedures for ensuring this transparency should be developed soon, and there is no need to wait for the two-year program of actions on governance reform. As with strengthening capacity of African Executive Directors' offices, this issue should not be allowed to remain unaddressed because it needlessly complicates the more important issues of quotas and voice reform.

\section{QUOTAS, VoICE, AND RAWLS}

Many policymakers, not to mention researchers, have commented that trying to understand IMF quota formulas is a formidable undertaking, yet the mathematics involved is nothing worse than the simplest algebra. One reason is that, even in the very first reading when one is busy trying to understand the formulas, it is difficult not to get bogged down into disagreeing with just about everything contained in the formulas and to start arguing why a particular variable is used, why it has more weight than some other variables, or why there are five distinct formulas, and so on. That problem could be overcome, to some extent, by practicing in advance of the need, that is, the first step in understanding these formulas should be to just peruse them without any comments, and then only afterwards go about disagreeing with the formulas. Even with this practice, one may find IMF quota discussions rather confusing unless one is careful in defining the objectives. The procedure followed in this section is: first, we discuss what the IMF quota formulas are meant to achieve; second, we simply state the formulas; and, third, we take issue with several aspects of the formulas, including the choice of variables, multiple formulas, and nonlinearities in the formulas. ${ }^{5}$

\section{A. Quota Formulas}

Quota subscriptions generate most of the IMF's financial resources, and total quotas at endSeptember 2006 were SDR 213 billion. Quotas perform several functions, including delineating basic aspects of members' financial and organizational relationship with the IMF:

Subscriptions. A member's quota subscription determines the maximum amount of financial resources the member is obliged to provide to the IMF. A member must pay its subscription in full upon joining the IMF: up to 25 percent must be paid in SDRs or widely accepted currencies (such as the U.S. dollar, the euro, the yen, or the pound sterling), while the rest is paid in the member's own currency.

Voting power. The quota largely determines a member's voting power in IMF decisions. Each IMF member has 250 basic votes plus one additional vote for each SDR 100,000 of quota.

\footnotetext{
${ }^{5}$ Readers familiar with IMF quota formulas may wish to skip subsection II.A.
} 
Access to financing. The amount of financing a member can obtain from the IMF (its access limit) is based on its quota. Under Stand-By and Extended Arrangements, for instance, a member can borrow up to 100 percent of its quota annually and 300 percent cumulatively. However, access may be higher in exceptional circumstances.

SDR allocations. A members' share of general SDR allocations is established in proportion to its quota.

Since quotas serve multiple purposes, the quota formula necessarily has to balance sometimes competing considerations about what variables to include in the formulas and the weights to attach to each variable. The formulas are overburdened by the multiple roles of quotas, and there is no particular need to have a rigid relation between financial contribution, access to Fund resources, voting power, and share of SDR general allocations. In fact, there are good reasons why the share of SDR allocations should not be linked to quotas. ${ }^{6}$

Regarding access, it is already the case that waivers are permitted to allow access outside the quota-based limits specified under the Articles (see Article V, Section 3 (b) (iii) and 4, under which use of Fund credit is limited to 100 percent of quota, unless waived). In our view, a cogent case can be made for fully delinking quotas from all decisions on access, but we realize that such an approach would raise a number of issues that would take us far away from our main purpose. Also, it would require an amendment to the Articles, and since this approach has received little support, we do not pursue it in this paper.

A formula used in 1944 when the IMF was established has become known as the Bretton Woods formula. ${ }^{7}$ This formula contained five variables: national income, official reserves, imports, export variability, and the ratio of exports to national income. This single formula was replaced by a multi-formula approach in the early 1960s, when the original formula was supplemented with four more formulas containing the same basic variables but with larger weights for external trade and external variability. However, this was not the end of the problem because two different data sets were used; there were in effect ten formulas. The quota formulas were simplified in 1981-82, including the following changes: (i) eliminating five of ten formulas by focusing on only one data set; (ii) replacing nominal income with GDP, which was viewed as a more comprehensive and readily available measure of national output; (iii) broadening the measure of reserves to include holdings of SDRs, ECUs, and IMF reserve positions and calculation of the holdings as a 12-month average rather than an end-of-period total; and (iv) reducing the coefficient of variability in the four derivative formulas by 20 percent to moderate the impact of the very sharp increases in the prices of certain commodities, especially the increases in oil prices in 1973/74 and 1979. These new formulas were supposed to help the developing countries because of their vulnerabilities to terms-of-trade shocks and reliance on a narrow range of exports. However, it is interesting to note that there are several industrial countries - and one G-7 country - that have calculated quotas determined by the new formulas. Also, the 60 year old Bretton Woods formula is used for more than one-third of the members, including many developing countries (see

\footnotetext{
${ }^{6}$ See Yaqub, Mohammed, and Zaidi (1996).

${ }^{7}$ For a more comprehensive overview of quota formulas, see International Monetary Fund, $2001 \mathrm{~b}$.
} 
Appendix Table). There have been no changes in the formulas since 1983, and the current five formulas are:

Reduced Bretton Woods formula:

$$
(0.01 \mathrm{Y}+0.025 \mathrm{R}+0.05 \mathrm{P}+0.2276 \mathrm{VC}) \times(1+\mathrm{C} / \mathrm{Y})
$$

Other modified formulas:

Scheme III formula:

$$
(0.0065 \mathrm{Y}+0.0205125 \mathrm{R}+0.078 \mathrm{P}+0.4052 \mathrm{VC}) \times(1+\mathrm{C} / \mathrm{Y})
$$

Scheme IV formula:

$$
0.0045 \mathrm{Y}+0.03896768 \mathrm{R}+0.07 \mathrm{P}+0.76976 \mathrm{VC}) \mathrm{x}(1+\mathrm{C} / \mathrm{Y})
$$

Scheme M4 formula:

$$
0.005 \mathrm{Y}+0.042280464 \mathrm{R}+0.044(\mathrm{P}+\mathrm{C})+0.8352 \mathrm{VC}
$$

Scheme M7 formula:

$$
0.0045 \mathrm{Y}+0.05281008 \mathrm{R}+0.039(\mathrm{P}+\mathrm{C})+1.0432 \mathrm{VC}
$$

where $Y=\mathrm{GDP}$ at current market prices for a recent year; $R=$ twelve-month average of gold, foreign exchange reserves, SDR holdings and reserve positions in the IMF, for a recent year; $P=$ annual average of current payments (goods, services, income, and private transfers) for a recent five-year period; $C=$ annual average of current receipts (goods, services, income, and private transfers) for a recent five-year period; and $V C=$ variability of current receipts, defined as one standard deviation from the centered five-year moving average, for a recent 13-year period. For each of the four non-Bretton Woods formulas, quota calculations are multiplied by an adjustment factor so that the sum of the calculations across members equals that derived from the Bretton Woods formula. The calculated quota of a member is the higher of the Bretton Woods calculation and the average of the lowest two of the remaining four calculations (after adjustment).

Just reading the last sentence could be sufficient reason to say that something is wrong here, if only because it takes a couple of readings to understand what is said in the sentence. One is left wondering why is the calculated quota the higher of the Bretton Woods formula and the lowest of the average of the remaining four formulas, given that this is after adjustment. Indeed, one could even ask the more basic question of why is there a need for five formulas when they have basically the same set of variables. It seems that the devil is both on the surface, but also, as usual, in the details. Since there are several formulas, a major problem is the absence of uniformity of treatment. For instance, the weight of the GDP variable differs across the formulas, and since different formulas are used for different countries, it is not the case that this purported measure of economic size gets the same treatment for all countries. This measure of economic size is in itself wrong because it uses market exchange rates to convert GDP to a common currency rather than PPP-based GDP. Nevertheless, there are problems with other variables as well, and these issues are discussed in Section III, starting with the GDP variable, but first we discuss how the Bretton Woods formula, which has been around for over sixty years, compares with some well-known ideas about social justice. 


\section{B. Original Bretton Woods Formula Versus Original Position}

According to the IMF staff, the original Bretton Woods formula was "a single equation intended to provide a comprehensive measure of the relative size of a country's economy that took into account important differences in the economic structures of countries." Be that as it may, its origin is dubious, to say the least. According to Raymond Mikesell, the economist in the US Treasury Department who worked out this formula, it was designed to attain a political objective, which he described in his memoirs:

In mid-April 1943, shortly after the White plan was made public, White called me to his office and asked that I prepare a formula for the ISF (original acronym for what became IMF) quotas that would be based on the members' gold and dollar holdings, national incomes, and foreign trade. He gave no instructions on the weights to be used, but I was to give the United States a quota of approximately US\$2.9 billion; the United Kingdom (including its colonies), about half the U.S. quota; the Soviet Union, an amount just under that of the United Kingdom; and China, somewhat less. He also wanted the total of the quotas to be about US\$10 billion. White's major concern was that our military allies (President Roosevelt's Big Four) should have the largest quotas, with a ranking on which the president and the secretary of state had agreed. I was surprised that White did not mention France, which was usually regarded as being third in economic importance among the Allied powers. He said he did not care where France ranked, and its ranking did not need to be an objective in the exercise. As was typical, White wanted something on his desk in a couple of days - it took me four, including a weekend. A modern computer would have saved several days of work on my state-of-the-art calculator and might have produced a more credible result. ${ }^{9}$

Mikesell also noted that, for several countries, data for some variables were missing and he had to rely on crude estimates: "I confess to having exercised a certain amount of freedom in making these estimates in order to achieve predetermined quotas. I went through dozens of trials, using different weights and combinations of trade data before reaching a formula that satisfied most of White's objectives." Deriving a quota formula to achieve a political objective, but one with little or no economic sense, was perhaps the biggest problem. However, it was not the end of the story because Mikesell goes on to write about how he made the formula nonlinear in variables: "I then found that I could get even closer if I increased the quotas by the ratio of average exports (from 1935 to 1938) to national income (1940)... The final formula for determining quotas was 2 percent of national income, 5

\footnotetext{
${ }^{8}$ See International Monetary Fund, 2005a, p. 29.

${ }^{9}$ Mikesell (1994), p. 22.
} 
percent of gold and dollar holdings, 10 percent of average imports, 10 percent of the maximum variation in exports, and these three percentages increased by the percentage ratio of average exports to national income." Unfortunately, by introducing the nonlinearity in the formula, White made it impossible to reach a clear economic interpretation of the formula. ${ }^{10}$ In particular, one cannot go from some considered judgments or agreements on what weights to give to the national income variable in the supply for quotas, and, accordingly, derive the calculated quotas for the countries because there is a multiplicative factor that increases the role of exports relative to national income in the determination of calculated quotas. In this instance, nonlinearity was introduced into the equation when there was no need for it, except to get as close as possible a fit to some precooked numbers. This is in sharp to the usual procedure in which equations are linearized by Taylor series approximation to derive meaningful results, i.e., when the real world is nonlinear, we make it linear via approximations to make it more tractable.

The quota formula was not distributed, and White asked me not to reveal it. Even though White wanted to suppress the formula, however, copies were circulating at the conference...After the list was distributed to the Quota Committee, more than half the delegates present strongly objected to the quotas for their countries, and several demanded to know how the quotas had been calculated. Vinson (Chairman of the Quota Committee), who had not been well briefed on the history of quotas, asked me to explain the basis for the list. I had anticipated this request and gave a rambling twenty-minute seminar on the factors taken into account in calculating the quotas, but I did not reveal the formula. I tried to make the process appear as scientific as possible, but the delegates were intelligent enough to know that the process was more political than scientific. ${ }^{11}$

The artificial complexity in the quota formulas or the lack of transparency reminds us of what one of the founders of the institution and Head of the British Delegation to the Bretton Woods conference, John Maynard Keynes, noted: "The Monetary Fund, in particular, has the great advantage that to the average Congressman it is extremely boring." ${ }^{12}$ Or what an

\footnotetext{
${ }^{10}$ Given the weaknesses of the quota formulas, they have been used only as a rough guide for determining actual quotas, either for adjusting quota shares or for setting up quotas for new members. There has not been any significant rebalancing of quota shares, although there have been major changes in the world economy, including sharp differences in growth rates of GDPs and exports among individual countries as well as different analytical groupings of countries. The distribution of selective quota increases, which have generally been based on calculated quotas, have not managed to eliminate the large discrepancies between actual and calculated quota shares. Most quota reviews provided for mainly equiproportional increases in quotas, and the selective increase component was not even used in some reviews. Also, quota formulas have had a limited role in determining the actual quotas of members when they join the IMF. Although the quota formulas are used as an independent measure of a prospective members' relative economic size, the quota resulting from the formulas - the calculated quota - is often very different from the actual quota assigned to the member.

${ }^{11}$ Mikesell (1994), pp. 35-36.

${ }^{12}$ Ibid., p. 445.
} 
associate of Keynes and noted economist Roy Harrod wrote about the debate on the Bretton Woods institutions: "[i]n view of the need for 'good handling' the less public lucidity there is on this matter the better." ${ }^{13}$ Contrast this with the widely accepted proposition in political philosophy that public justification should be a never-ending commitment because citizens and governments are always confronting new circumstances, as clearly articulated in the following quotation from Macedo:

...we could have no confidence in our reasons for committing ourselves to what we understand justice to be unless we keep debating it and remain open to new and better interpretations of it. We cannot honor our status as reasonable beings unless we remain open to a critical dialogue about the justifiability of our deepest political conceptions, whatever they may be...Public justification is not a means only but also an end in itself: being a self-critical reason giver is the best way...The reflective, self-critical capacities we associate with public justification must, therefore, be regarded as permanent and ever-developing characteristics of liberal citizens at their best. ${ }^{14}$

For the purposes of this paper, we would suggest replacing "liberal citizens" with "international institutions" in the last sentence.

The reader is also asked to contrast the above discussion about the original Bretton Woods formula with what John Rawls, arguably the greatest political philosopher of the $20^{\text {th }}$ century, had called the "original position" in his theory of justice. ${ }^{15} \mathrm{He}$ had emphasized that, in light of their reasonable economic, philosophical, and moral disagreements, members in a cooperative institution or citizens in a society will willingly and freely support a regime only if the political conception on which it is founded can be the object of "an overlapping consensus." At the risk of oversimplification, Rawls's theory of justice has two parts. In the first part, the original position is constructed to permit a theoretically rigorous way of moving from disagreement or uncertainty about the requirements of justice to an answer that is a reflective equilibrium. The original position is formed in light of beliefs about justice that are held in the community, or on which there is agreement, and the procedure is to see if the parties in the original position would decide on definite principles of justice. The second part is devoted to establishing the principles that would be agreed upon in the original position.

The idea of the original position may be viewed as a hypothetical situation in which agents acting as trustees for the interests of concrete individuals or countries are pictured as choosing those principles of social relations under which their principals would do best. Their choices are subject to certain constraints that are required to embody the specifically

\footnotetext{
${ }^{13}$ Moggridge (1980), p. 267.

${ }^{14}$ Macedo (1990), pp. 287-88.

${ }^{15}$ Rawls (1987, 1988, 1989, 1996, 1999).
} 
moral elements of original position argumentation. In particular, the trustees do not know facts about their principals which are morally irrelevant to the choice of principles of justice. This restriction in their reasoning is embodied in Rawls's so-called veil of ignorance, which screens out information, among other things, about principals' age, sex, wealth, and education when discussing individuals; population, national output, level of development, etc., in the present case of considering countries in the IMF. Once this information is unavailable to their agents or trustees, the plurality of interested parties disappears. Accordingly, the problem of choice is rendered determinate because each individual's trustee has the same information and motivation as every other individual's trustee. Therefore, the original position is a situation of choice, not of "negotiation" between a plurality of distinct individuals. Original position argumentation is a primary example of what has come to be called contemporary contractualism in political philosophy, which involves a pureproceduralist approach to the determination of moral principles, and is framed by reflective equilibration with widely agreed principles of justice.

Rawls argued that ordinary individuals would never be able to get a sense of the just structure of social institutions if they only behold the world from their limited perspectives. The key to social understanding does not lie in an immersion in the details of particular cases or institutions, but the precise opposite: for example, getting sufficient distance from the particulars of one's own country. To make this system work, an individual has to shed any attachment to the particular interests of his country, and, in order to guarantee their reasonableness, Rawls puts his hypothetical subjects behind a "veil of ignorance" to capture that sense of remote impartiality. The veil of ignorance removes from their sight the morally irrelevant factors that distinguish them from other trustees, which allows their choice to be fair principles for social cooperation. Specifically, Rawls posits that a just social contract is that upon which the trustees would agree if they did not know in advance what sort of position their countries would occupy in the institution they are joining. In the original position, the trustee would not know the economic size, financial situation, or other morally irrelevant facts about the country and, from behind the veil of ignorance, the trustees would be able to discern the form of a truly just international institution. Put differently, the process used in the design of institutions is of crucial importance for justice, and the original Bretton Woods formula is as far away from the Rawlsian original position as the two poles of a magnet, but there is a difference in that, unlike the opposite magnetic poles, these two "originals" are not attracted to each other.

Rawls's theory is an end-result approach insofar as choice of principles is reached behind a veil of ignorance - the choice must be based on calculations about what people are likely to end up with under the various possible sets of principles - but Nozick (1973) has provided an alternative or historical theory of justice. Nozick's entitlement theory does not require that the just distribution should be correlated with, for example, moral merit, need, or usefulness to society. In this approach, people may be entitled to things obtained by chance or as a gift. In general, any distribution, irrespective of any pattern it may or may not have, is just if it has the appropriate history, or, in other words, it has come about in accordance with the rules of acquisition, transfer, and rectification. We have worked with Rawls's theory but it should be 
clear that IMF quota formulas do not meet Nozick's test either. ${ }^{16}$ These formulas determine, among other things, the distribution of voting power in the IMF. However, they were simply the numbers decided by Secretary White, and were not based on any rules of acquisition, transfer, or rectification. Treasury staff economist Mikesell was asked to come up with a formula that would justify the precooked numbers, which means that Bretton Woods formula does not have what Nozick would call "appropriate history" and there is no basis for discussing any rules of acquisition or other requirements of the entitlement theory.

\section{RAWLS'S METHOD}

Rawls's idea of reflective equilibrium expressed his political understanding of justification but in a more complicated way than is usually thought. To justify the claim that some particular conception of justice is the appropriate one, Rawls argued that this could be done by finding that conception which is best fit to play the role of adjudicating competing claims on scarce social resources or distribution of power. Furthermore, to judge fitness for this purpose, he emphasized that no conception of justice can play such a role unless there is widespread "up-take" of its basic principles and deliverances. Hence, we see, for each candidate conception, whether its implications can be brought into reflective equilibrium with the considered judgments of justice in a particular community. If that cannot be done, then up-take will not be secured and the conception cannot facilitate mutual benefit. This is what distinguishes principled reasoning about justice in a "pragmatic mode" from the modus vivendi argument that Rawls repudiated in no uncertain terms. ${ }^{17}$ Before discussing the applications of the reflective equilibrium and overlapping consensus to the voice and quota debate in the IMF, it is illustrative to first discuss the current state of play, and next, contrast it with the Rawlsian approach.

\section{A. Quota Formula Review Group (QFRG)}

Given the concern that the quota formulas did not reflect changes in the world economy, such as the growing role of emerging markets and the increased importance of international capital flows, the IMF convened the Quota Formula Review Group (QFRG) in 1999 to provide an independent review of quota formulas. ${ }^{18}$ The eight-member panel, chaired by Professor

\footnotetext{
${ }^{16}$ Nozick provided an apt characterization of his approach to philosophy in his last book: "My own philosophical bent is to open possibilities for consideration. Not to close them. This book suggests new philosophical views and theses, and the reasons it produces for these are meant to launch them for exploration, not to demonstrate conclusively that they are correct... Similarly, my criticisms of some major competing theories or positions are not intended to refute them conclusively, merely to weaken them enough to clear a philosophical space in which the newly proposed views can breathe and grow." Nozick (2001), p. 3. One cannot help but think that Nozick had his good friend Rawls in mind when he wrote the last sentence in this quotation.

${ }^{17}$ Working within the framework defined by the veil of ignorance and derived from this widely shared concept of justice, rational calculators choose principles of justice on the basis of their fiduciary duty to the concrete individuals or countries whom they represent. Their choice is not of an objectively correct conception of justice; it is, rather, of that conception which is best fit to play a certain kind of social role in the community whose members are represented in the original position.

${ }^{18}$ See International Monetary Fund, External Review of Quota Formulas, (2000a, 2000b, and 2001a).
} 
Richard Cooper (Harvard University), was asked to review the quota formulas with respect to "their adequacy to help determine members quotas ... in a manner that reasonably reflects' members relative positions in the world economy as well as their relative need for and contributions to the IMF's financial resources, taking into account change in the functioning of the world economy and the international financial system in light of increasing globalization of markets." The QFRG recommended a single formula with two variables: GDP as a measure of the ability to contribute resources to the IMF and variability of current receipts and net long-term capital flows, as a measure of external vulnerability, with the GDP variable having the larger weight.

We will not comment on the obvious problem that the specific formula recommended by the panel pointed toward a greater concentration of quotas among the largest industrial countries, a result which is unacceptable because it is in the opposite direction from what are the universally acknowledged objectives of the quota reform, namely, giving more voice to: (i) the emerging countries because of their relatively faster growth rates and increasingly larger weight in the world economy, and (ii) the low-income and small countries to address the Westphalian and democracy deficits. Instead, we confine our comments to the specific variables suggested by the QFRG. They recommend the use of GDP, converted to a common base at market exchange rates, and a broader definition of variability to indicate potential vulnerability. The problem with the first variable is that the alternative PPP-based measure of GDP is superior for the task at hand (see below). The problem with the second variable is that QFRG variability measure did not reflect vulnerability to short-term capital shocks, nor did it take into account the fact that capital account disruptions in developing countries are not just different in degrees, but in kind, from those in advanced economies and, accordingly, should be measured using different metrics (see below).

Several difficult issues remain to be resolved, including agreeing on the precise weights of each variable, but there are major concerns among many Directors, particularly those representing the developing countries, that the voice and quota debate is being narrowed down and some important issues are not being addressed. For example, recent staff papers have noted that "[i]n June 2002, Executive Directors reached understandings on broad principles for arriving at an alternative quota formula...there was general endorsement of a simpler and more transparent approach in specifying the variables in quota formulas...that variables included in the quota formulas should be indicators of members' economic position in the world...also agreed to limit consideration to three or four variables used in existing quota formulas, but updated and modernized. These variables include GDP, a measure of openness, variability, and possibly international reserves...Board reaffirmed these broad conclusions in the July 2003 discussion on quota-related topics." 19

\footnotetext{
${ }^{19}$ There has been a disappointing rush toward eliminating certain variables from further discussion and/or to downplay their possible inclusion in the quota formulas. Statements such as the following are not helpful for advancing the very contentious debate on quota reform: the possibility of using purchasing power parity rather than market exchange rates to derive GDP was discussed in October 2001 when a "majority of the Board considered that market exchange rates should be used to convert GDP to a common currency." It is disconcerting that, in this instance, little consideration was given to the fact that many Directors had very strong views on the need for PPP-based measures of GDP. In a similar vein, staff note that at the discussion in September 2005, most Directors reconfirmed that a revised formula should be based on an updating of the
} 
The following discussion takes as a starting point the QFRG's suggested criteria for assessing proposals for changes in the formulas, notably a focus on variables that reflect changes in the world economy, consistency with the multiple functions of quotas, and simplicity and transparency, but goes further in analyzing additional variables that could be included in a revised formula. We propose a new way of looking at the quota formulas, which overcomes the main shortcomings of the present approach, and one which we think will go a long way in addressing the democracy deficit and the legitimacy problems facing the IMF.

\section{B. Variables in the Quota Formulas}

Economic size: The advanced countries have favored using the three-year average (in lieu of the recent year) of GDP at market exchange rates as the most important variable to be included in any new formula because they view it as the best indicator of countries' economic size and of their potential to either provide to or use of IMF resources. ${ }^{20}$ However, most economists would agree that using purchasing power parity rather than market exchange rates to derive GDP would be the more appropriate procedure. The variable is meant to capture economic size, but this cannot be done using market exchange rates because there are wide variations in common currency prices for the same commodity bundle across countries, with distortions being particularly severe in the case of developing countries. The argument that market exchange rates should be used to convert GDP to a common currency, so as to obtain the best measure of the total amount of resources generated by a country, has an irony embedded in it. If one is measuring economic size, there is no argument but that the PPP measure is clearly the right metric because the same bundle of goods gets the same measure. ${ }^{21}$ The counter argument would be that all bundles of goods cannot be sold in the international market, i.e., economies contain two sorts of activity: tradable, i.e., manufacturing and services that can be supplied at a distance; and non-tradable, i.e., haircut, childcare, etc.. The irony and major weakness of this counter argument is that nobody is possibly imagining an IMF so large that countries would have to attempt to sell their nontraded activities on the international market to come up with the financing of their quota shares; the present IMF quota of any country is a tiny share of its foreign transactions.

traditional economic and financial variables and should comprise at most four variables. ${ }^{19}$ This sentence has the same problem of not giving weight to the diversity of views expressed on alternative variables that may be included in a new quota formula but makes an even bigger mistake by pushing the discussion toward an inexorable and mistaken conclusion of sticking close to the flawed formulas. Moreover, it does not recognize that the holistic approach, in which basic votes are increased, could have other implications for the quota formulas that are yet to be discussed. See International Monetary Fund, 2005b.

\footnotetext{
${ }^{20}$ The proposal of using a three-year average for GDP works to the advantage of the industrial countries because it postpones the incorporation into the quota formula of the catching-up effect on the GDP variable of the fast-growing emerging market economies and LICs.

${ }^{21}$ See McLenaghan (2005) on the progress that has been made in compiling PPP-based GDP for developing countries, which has largely taken care of the oft-repeated problem that this measure is not available for a large number of countries.
} 
Openness: Some countries have been strong proponents for the inclusion of an openness variable. This is specified as the absolute sum of current receipts and current payments, averaged over a five-year period, to reflect countries' integration in the world economy. There is also support for broadening the openness measure by including a variable for financial openness, although there are data difficulties that first would need to be resolved. Setting aside the problem of the correlation of openness with other variables in the formula, it is clear that this variable also suffers from a second, closely-related problem, which is the treatment of trade within currency unions. In particular, given the emphasis being placed on the so-called "modernizing" of the traditional variables in the quota formulas, one would think that attention would focus on adjusting the treatment of trade within currency unions, not least in light of the fact that the European Single Market was completed in 1992, and moreover, euro was adopted as currency by a number of these countries in 1999. There is not that much difference, say, in the trade between Belgium and Luxembourg, and between two provinces inside a country. For the purposes of quota calculations, the IMF staff have used techniques in the past to exclude certain receipts and payments in order to avoid exaggerating the size of the external sector, such as in the case of excluding certain interest payments and entrepot trade. However, the question of trade within the currency unions is of far greater significance for relative quota shares than the exclusions currently being practiced, but unfortunately, this debate has proceeded rather slowly. Above and beyond this consideration, the problem is that the openness variable is supposed to capture the demand for IMF resources. However, as discussed below, there are far better proxies for the demand variable in that they have far higher correlations with the actual use of IMF resources than the openness variables currently being used. ${ }^{22}$

Variability: The inclusion of a measure of variability of current receipts and net capital flows appears to be warranted, in order to capture countries' vulnerability to balance of payments shocks in the quota formula (and the attendant potential demand for IMF resources). There is general support that variability be specified as deviations from a threeyear average, which would serve to smooth trends while adequately capturing the fluctuations in capital flows. As noted below, there is a strong case for supplementing the variability variable with others that capture the demand for IMF resources.

Reserves: It can be argued that reserves are a useful indicator of members' financial strength, and should be retained as a variable in the quota formula; this is also consistent with recent emphasis on adequacy of international reserves. The counter argument would be that, for many members with access to capital markets and floating exchange rates, reserves are of declining importance and should be excluded. However, high reserves can be a useful indicator for both demand and supply of IMF resources, and it ought to be retained (see below).

\footnotetext{
${ }^{22}$ Hence when one asks 'qui bono?' (who benefited?) from these quota formulas, the main countries (in relative terms) include the advanced countries and the countries belonging to the European Union, all of which benefit from the market-exchange-rate-based GDP and the openness variables.
} 


\section{Reflective Equilibrium}

Rawls noted that to facilitate the achievement of certain goals, we should understand the circumstances that make it necessary to develop and propagate the principles of justice. Suppose that scarcity of supply relative to demand for IMF quotas is characteristic of our situation, which seems reasonable because there is no price mechanism to equate supply and demand. Moreover, there is no example of any country voluntarily offering to lower its quota share. This is part of what makes the propagation of distributional principles and practices necessary: given scarcity and certain other factors, countries will not individually, or collectively, self-equilibrate to ensure demand-supply equilibrium. However, it is exactly this fact that should be captured in the procedure applied for the development of these principles, which the trustees have to take into account if they are to achieve justice. If they just assume away the problem of distribution by presupposing, for instance, that countries will spontaneously adjust their demands and supplies to achieve an equilibrium-because there is a price variable that is adjusting - then they would have completely ignored the fact that the quotas are not traded and that there is no price variable attached to them. One can imagine the public reaction if the global leaders of a particular industry colluded to suppress the workings of the free market and arbitrarily fixed the price of their goods, or the capital subscription in their firms were not allowed to be traded. There would be an outrage that there was conspiracy and restraint of trade, and the corporate heads would be asked to implement reforms to improve governance. If the IMF is only a financial institution, why then are its capital shares not traded, or its lending terms arbitrarily fixed, and the market mechanism does not play a role. ${ }^{23}$ Given the important differences between the IMF and other financial institutions, it seems odd not to recognize the unique nature and responsibilities of the IMF, and even odder that some recognize the need for quotas and voice reform, but then insist that the variables in the quota formulas should be confined to just a couple of economic variables, which severely biases the representation of developing countries.

In what has become known as the Rawls test, policymakers should always ask themselves the question: "Would the best-off accept particular social or economic arrangements if they believed, at any moment, their fortunes were reversed and they were to be placed in the position of the worst off?" The present IMF structure does not fit Rawls's conception in many respects. Apply his method to the openness variable in the quota formula and ask whether we would, behind a veil of ignorance, opt for this variable, which ostensibly is meant to capture the demand for IMF resources. This would only be fair if it could be shown that the openness variable is the best metric for gauging which countries borrow from the IMF. However, some of the countries that score the highest in terms of this variable and, therefore, benefit the most in terms of quota shares, have had no need for IMF resources for the last 25 years; in fact, some of these countries have never borrowed from the IMF. As discussed below, a straightforward approach to capturing the demand for IMF resources in the quota formulas would be a variable that takes into account the history of borrowings by a member country and/or

\footnotetext{
${ }^{23}$ Unlike shares in a joint stock company, IMF quotas are not traded in a market and as such there is no marketclearing price for these quotas or share subscriptions.
} 
external vulnerability (e.g., credit ratings on sovereign borrowing or spreads on sovereign debt).

Since the present quota formulas have severe weaknesses and are not well-designed to capture the likelihood of borrowing from the IMF, the interests of debtors were not taken sufficiently into account. However, it would be wrong to stretch the "original position" argument so far that it forces one into the untenable position of defending, for example, the proposition that IMF quota formulas should be the equilibrating mechanism that balances out all other inequalities, injustices and effects of luck so as to make members indifferent between being an advanced economy and being a developing economy. To say that the trustees are behind a "veil of ignorance" is to say that they do not know the following sorts of things: their countries' economic size, level of economic development, population, possible need for IMF resources, etc.. However, they are aware of the general types of possible situations in which countries can find themselves and the purposes of the IMF, such as multilateral and bilateral surveillance, provision of conditional liquidity (IMF-supported adjustment programs) and provision of unconditional liquidity (SDRs). The original position argument has to used with some care, namely, to imagine a situation in which a group of individuals are brought together to agree upon the basic constitution of a society or social institution that they are about to enter, but in which, to ensure their impartiality, they are placed behind a veil of ignorance. In the present context, self-interested rational persons behind the veil of ignorance are given the task of choosing the principles that shall determine the governance structure of the IMF. In deciding what the quotas formula should be for determining, among other things, the distribution of the voting rights in the IMF, we should try to imagine what formula the representatives of the countries would choose if they didn't know what type of country they were going to represent. The veil denies them any knowledge that is morally irrelevant. With the expulsion of bias-inducing knowledge, the participants in the original position are forced, even if self-centered, into the moral point of view, which allows Rawls to claim that he has set up an inherently fair procedure, and the principles to be chosen by means of this procedure would be fair.

In sharp contrast to what the Rawlsian approach would require for justice as fairness, it is clear that creditors would mind if they swapped positions with debtors. Since this is not the case, the present quota shares do not pass the fairness test. ${ }^{24}$ One implication of this failure to

\footnotetext{
${ }^{24}$ It is hard to imagine the advanced countries ever being asked to implement such programs. It is very important to note that Rawls's model of "purity of heart" has two parts: first, the description of people or trustees in the hypothetical situation of choosing principles for cooperation. They are imagined as rational, selfinterested individuals who aim at doing for themselves as well as possible, and who have needs that can be met more effectively by cooperation than noncooperation. They do not know the size of the territory, population, financial situation, or the level of their economic development, or other such information of the people whose fundamental interests they represent. However, they do know that reasonably favorable conditions are attained by having an institution like the IMF, i.e., international monetary cooperation is worthwhile. Second, the method enables each trustee to secure his ends, subject to certain circumstances, conditions, and constraints, but what is of considerable importance is that their justification does not reflect some antecedent understanding of what justice is, metaphysically, or conceptually. This is one of the strengths of Rawls's approach, namely, that it is meant, specifically, to correct for any mistaken understandings that might nevertheless be widely diffused. The basis for correction is a pragmatic one insofar as it addresses the question of how well does this understanding facilitate the achievement of certain goals.
} 
pass the Rawls's test is that the IMF programs have been overloaded with conditionalityrecall the programs during the Asian financial crisis in which programs had more than a hundred performance criteria or benchmarks and the subsequent deliberations that led to the streamlining of conditionality. The following quotation from Hubert Neiss, who was Director of the Asian Department during the Asian financial crisis, gives an idea about the design of the adjustment programs and the involvement of the Executive Board.

In the end, programs had to be approved by the Fund's Executive Directors, who represent member governments and whose votes are weighted by the economic importance of the countries they represent...Governments' views were obtained through regular informal contacts with the Executive Board during the program negotiations (in the case of Indonesia, including two video conferences), as well as in discussions with the Paris Club members. It was amply clear that the international community required comprehensive action...I do not think the Board would have accepted programs which failed to dismantle the monopolies in Indonesia which were a main source of corruption; or in the case of Korea, failed to liberalize foreign ownership and take-over rules in order to attract capital into the financial sector and introduce effective competition, or to make changes in the labor laws to allow corporate restructuring. Similarly, programs failing to revise bankruptcy and foreclosure laws in Thailand and Indonesia, in order to allow effective debt restructuring, would have been considered inadequate. And in all cases, programs would not have been passed without including extensive privatization, an area that is not mentioned in the Fund's Articles. ${ }^{25}$

An extensive comment on whether conditionality was excessive-or on the question of mission creep that seems to be implied in the last sentence of the quotation-would take us too far from the main focus of this paper. Accordingly, we confine our comments, first, to the point that the industrial countries have over 60 percent of the votes in the Executive Board, and this majority does matter in getting a sense of the views of the Directors and the governments they represent, and, second, refer the reader to the article by Alan Blinder, former Vice Chairman of the US Federal Reserve Board, in which he called for major reforms:

As I stated at the outset, the new financial architecture needs to give greater weight to developing and strengthening the social safety nets that shield innocent bystanders from the fallout of financial crises. This idea is not alien to the IMF's way of thinking. But neither is it central. The IMF pays inadequate attention to the protection of innocents - compared, say, to the protection of creditors who have made ill-conceived loans...A reformed IMF, working in conjunction

${ }^{25}$ Neiss (2001). 
with the World Bank and regional development banks, should ensure that foreign creditors are not bailed out while local populations drown. ${ }^{26}$

The Blinder quote is not about quotas but about the criteria that should be used in designing adjustment programs and then judging whether they are succeeding or failing. Whereas his paper aims to persuade people in the "high quota" countries to reform the IMF, it is relevant for the quota debate insofar as it makes clear that the design of adjustment programs needs to be improved. We discuss in the next subsection that any progress made in improving the distribution of quotas would also mean progress in addressing the problem of program ownership and the design the adjustment programs because those who approve the programs (i.e., the Executive Directors) would include a significant proportion of people whose economies are directly affected by those programs.

What are the implications of the original position argument for the conditionality debate and IMF governance? An answer would be that a self-interested rational person behind the veil of ignorance would not support a governance structure that gives almost no weight to the Westphalian principle of "one nation, one vote" and an exact zero weight to the democratic principle of "one person, one vote." In particular, such a person would not wish to represent either a small country that gets almost no voting power-basic votes reflect the Westphalian principle but give a mere $1 / 100^{\text {th }}$ of 1 percent of the voting power to each country - or a country with millions of people, when the democracy principle is not even acknowledged. Another answer would be that a rational person would not want to support a governance structure in an institution to which members cede some important aspects of national sovereignty in the interest of global monetary cooperation, and whereas the institution impacts in important ways - not only when there is an IMF-supported adjustment program, but also because of IMF's surveillance, regulatory and policy advice activities - the livelihoods of hundreds of millions of people, the governance structure does not give any weight to the population variable in the quota formula. Looking forward, this point bears emphasis because the IMF's lending role is becoming less important relative to surveillance, technical assistance, and other activities, which would suggest larger weights for the Westphalian and democracy principles and smaller weights for the traditional creditor/debtor variables.

It has been argued by some observers that even though population is not included in the quota formulas, there is some correlation between population and some other included variables, such as GDP and external receipts. There are at least three ways in which this argument fails. The first deals with the simple fact that since data are available on population, and if that is the variable we are trying to capture, then there is no need for a proxy variable. Second, the correlation coefficient between population and some other variables would be higher than between it and GDP or exports. In particular, the correlation of population with a PPP-based measure of GDP would be higher than with GDP calculated with market exchange rates. Third, this argument is wrong because, as we have seen, GDP was meant to

\footnotetext{
${ }^{26}$ Blinder (1999), pp. 59-60.
} 
capture a country's economic size and ability to contribute to IMF resources, while international receipts were meant to capture the possible borrowings from IMF. These variables cannot account for our sense of ourselves as "self-interpreting" and "self-reflective" beings, or in other words, that the self (in the abstract, general sense) is prior to its ends. Put simply, the worth of human being qua human being cannot be measured by some aggregate economic concept.

Despite the need to incorporate additional variables in the quota formula, the IMF Board is moving toward accepting the recommendation of the QFRG to have a simpler approach in specifying the variables in a new quota formula that would replace the existing ones and that the variables included in this formula should be indicators of members' relative position in the world economy. Unfortunately, population is not one of the variables that has received much attention. Also, little progress has been made in these discussions towards agreement on a new metric to measure members' relative economic positions and capital flows. Somewhat more progress has been made in terms of limiting consideration to three or four variables used in the existing quota formulas, but updated and modernized. These variables include GDP and measures of openness, variability, and possibly official international reserves, although no consensus has emerged on the weights to be used in aggregating the variables in a new quota formula. A major difficulty is a high correlation among the variables in the current quota formulas and the need for further work to reduce this correlation, including the inclusion of additional variables. The correlation among variables means that the coefficients attached to each variable cannot be taken to represent the variable's relative importance in a new quota formula. ${ }^{27}$ There is also significant support for the view that GDP is the most important indicator of economic size and should have a higher weight than in the current formulas, but, unfortunately, the major shareholders oppose the PPP-based measure of GDP.

The openness variable, which supposedly captures the demand for IMF resources, has generated as much controversy as that relating to the PPP versus market exchange rate in the conversion of the GDP variable to a common currency. Whereas there is considerable support for the view that a capital flow volatility variable be included in the quota formula, the measures proposed by the staff have major shortcomings. However, the idea to capture countries' vulnerabilities to capital account shocks in the quota formula is clearly correct, not least given the number of financial crises that many IMF members have faced since the late-

\footnotetext{
${ }^{27}$ It should be emphasized that this is not an argument about some problems in econometric estimation, or more specifically that multicollinearity would reduce the precision of the estimated coefficients, because there is no econometrics involved in determining IMF quotas. Instead, our argument is against the point that has been raised by some observers that the quota formulas are an attempt to capture the weights that different properties of economies have and that are relevant for the voting power, access levels, SDR allocations, etc., and if these properties are correlated across countries, so be it — that's our choice and there is no multicollinearity problem. This argument is wrong because it is not a multicollinearity problem in the econometric sense that is being discussed, but the simple point that if two variables are very highly correlated, adding the second variable into the equation does not bring with it much additional information; even though these variables may seemingly represent different characteristics, but the high correlation means that the dominant underlying factor would be the same for these variables. Put it differently, when there are many variables that are highly correlated, just a few principal components would capture most of the information
} 
1980s and during the 1990s. The idea received support in the G-24 Ministers' communiqué of October 2004, which stated that enhancing the representation of developing countries requires a new quota formula and specifically mentioned the need to take into account their vulnerabilities to the volatility of capital movements. The current quota formula estimates a country's vulnerability only to current account shocks, by including variables such as trade openness and export volatility. In recent years, however, many of the balance-of-payments crises have been of the capital account variety, which are related to developments in financial markets and often precipitated by exogenous factors, such as contagion and "sudden stops". Although recent IMF Board discussions on quota formulas have emphasized the need for a measure of capital flows volatility, the problem with variables that have been analyzed by the staff is that they do not capture the countries' macroeconomic vulnerability to capital account shocks. ${ }^{28}$ The capital flow variables examined by the staff are either just gross capital flows or volatility measures that have not been normalized to reflect major differences across countries. Thus, the variables under consideration are not a good measure of the amount of resources potentially required to stabilize a given country. It should be apparent that if two countries experience the same capital account shock in absolute terms, the smaller economy will face a greater burden. The first step should be to measure net capital flows as a proportion of the size of the economy-by measuring volatility of capital flows as a proportion of GDP — which is the alternative evaluated in the paper by dos Rios (2005).

Furthermore, measuring volatility of capital flows as a proportion of GDP is only the first step because of the important differences between the capital flows of industrial versus developing countries that should also be addressed. Some recent open-economy theoretical models, including a few third-generation currency crisis models have incorporated these differences. For example, a key insight from the dual liquidity models developed by Caballero and Krishnamurthy, which bears directly on the question of the capital flow variable in the quota formula is that for many emerging markets with international liquidity shortages, there is a sharp distinction between international and domestic collateral unlike the case in industrial countries. The Caballero-Krishnamurthy model, henceforth $\mathrm{C}-\mathrm{K}$ model, which emphasizes the financial constraints affecting borrowing and lending among agents within the economy - as distinct from those constraints affecting borrowing from foreign lenders - also points to the need for substantial international liquidity in emerging markets. ${ }^{29}$ In the $\mathrm{C}-\mathrm{K}$ model, international liquidity constraint is defined as a situation in which domestic agents have sufficient collateral to borrow from other domestic agents, but cannot borrow from foreigners because the country's shortage of international collateral. ${ }^{30}$

\footnotetext{
${ }^{28}$ See, for example, dos Reis (2005).

${ }^{29}$ Caballero and Krishnamurthy (2001).

${ }^{30}$ The Caballero-Krishnamurthy model focuses on two distinct situations, which have sharply divergent implications for the conduct of monetary policy. In the horizontal view, the distressed firms are constrained in meeting their financing needs because they have limited collateral, that is, their total liquidity is insufficient to meet the higher financing needs due to the production shock. This situation is termed horizontal, because the international financial constraint is not binding for intact firms, and the interest rate they charge against domestic collateral is equal to the international interest rate. In contrast, the vertical view is the situation where the international supply of funds is vertical, because there is a shortage of country-wide international liquidity.
} 
Another major difference between the capital flows of industrial versus emerging market countries is that in the latter case, external debt is overwhelmingly denominated in foreign currency, which has its own problems apart from those relating to the dollarization of liabilities in the banking system. One explanation for why emerging market countries have not been able to borrow abroad in their own currency is that they have pursued financial policies that have resulted in high inflation rates and depreciating exchange rates. Another explanation is that they have not built the social institutions required for policy credibility, which makes investors reluctant to invest in domestic currency assets. Furthermore, if these countries were to issue debt in their own currencies, there is the risk that even those that had hitherto pursued sound financial policies might be tempted to pursue more inflationary policies as a way of eroding the real value of their external debt. However, even emerging market countries with low inflation, balanced budgets, and good governance have not acquired immunity against this problem. It is not clear what these countries have done to bring this problem upon themselves and because foreign currency debt is the source of many other problems, it is referred to as "original sin" in the literature. 31

These considerations suggest that the capital flow variable for developing countries cannot be put in the same basket as that for the industrial countries because that would be mixing apples and oranges together. One promising approach would be to attempt to assess the demand for IMF resources by emerging market countries by examining the ratings assigned to these countries by major rating agencies. Yaqub, Mohammed, and Zaidi (henceforth YMZ) proposed in the context of SDR allocations that one should start with the group of countries that received concessional financing from the Poverty Reduction and Growth Facility (PRGF), and to broaden this group by including other emerging-market countries that have not received investment grades by credit rating agencies, such as Moody's and Standard and Poor's Investor Services. It seems quite straightforward to use a modified YMZ approach in the quota formulas, and it would be a more appropriate measure for the demand for IMF resources than gross capital flows that have garnered most of the attention in the quota formula debate.

Without getting involved in a debate about the credit-rating agencies, it may be mentioned that the scheme just mentioned relies heavily on the credit rating agencies for the determination of quotas, which could be a source of concern for some observers. There has been some controversy about the reliability of the ratings and the lack of transparency, particularly in light of the rating agencies' failure to warn investors about the impending bankruptcy of some major companies in the past couple of years. In light of the foregoing discussion, it would be useful to modify somewhat the YMZ approach and replace their second criterion based on ratios of reserves to imports with a broader set of indicators. The

In the vertical framework, international reserves are an important component of liquidity, because here the supply of international liquidity is inelastic, with foreign investors unwilling to provide additional funds and domestic agents resorting to hoarding of whatever little they have of international liquidity.

${ }^{31}$ See Eichengreen and Hausmann (1999), p. 11. 
new method would have the advantage of bringing more continuity in the variables by using a wider information base. In addition, it would be more of a hybrid approach because, instead of relying on ratings assigned by the major agencies or reserve-import ratios, one would start with three or four variables, which could include reserves to short-term debt, financing gaps, and monetary base (or money supply) ratios. Including reserves to short-term debt would follow the suggestions of Guidotti and Greenspan regarding self-protection policies and because empirical crisis-prediction models have shown that this ratio is an important factor in determining a country's vulnerability to financial crisis. ${ }^{32}$ The reason for including the ratio of monetary base (or money supply) to reserves is that, as discussed in the Chang-Velasco and Dooley models, the size of a country's monetary base (or money supply) in relation to its reserve holdings is an important indicator of the country's potential exposure to the withdrawal of assets and, hence, a country's vulnerability to crisis. ${ }^{33}$ One could also use sovereign bond spreads to measure the likely need for IMF-supported adjustment programs. Needless to say, several of these variables would have high correlation, and one could either eliminate those variables with the highest correlations, or the demand variable in the formula could be a weighted average of several of these variables, but, as emphasized in the Rawlsian approach, the total weight of the demand variable in the formula would be agreed upon at the outset.

The foregoing discussion shows that simple variables do not always perform the task assigned to them because there are cases in which the situation could seemingly be classified in a known type through a particular variable, but one would not be comfortable with the implementation of the simple "ready-made variable." We know that judgment according to that variable involves a certain amount of misfit between the general rule and the particular situation at hand. Even if we were to assume, for the sake of argument, that there is no misfit and we attempt to act according to a simple rule and a simple variable, we should be open to the point that we are still not dealing with the situation in which we stand, but that we are dealing with a certain type of situation under which we class it. For example, if a particular variable in a quota formula may appear at first glance to be similar to the general concept we are trying to measure, it is nonetheless true that, although the general concept provides us with a handle with which to grasp the particular situation, we still have to recognize that the generality of the rule interferes with the specific aspects of the situation we are trying to grasp. In other words, for all of the reasons mentioned above for the special and unusual aspects of the capital account variable, it is clear that the difference between the capital flows of developing countries and those of the industrial countries are not just a difference in degree but a difference in kind, between the generality of the capital account variable and the specific situation at hand. Therefore, insight and careful deliberation are required in the decision-making process of quota formulas, and we can not say that 100 percent of decisions about variables in these formulas could be easily determined by a strict application of the rule that the same variable applies to both advanced and developing countries. It is for these reasons that the quota formula should treat some variables differently for industrial and

\footnotetext{
${ }^{32}$ See Radelet and Sachs (1998) and Berg et. al. (1999).

${ }^{33}$ See Calvo (1996).
} 
developing countries, and, while simplicity of the formula is important, it needs to be balanced with the need to capture the main objective of the exercise. These considerations suggest that the quota formulas should have moral and economic underpinnings, not just political underpinnings; two secondary conclusions are that the formulas are worse than useless unless they are designed properly and, with apologies to Albert Einstein, quota formulas should be made as simple as possible but not simpler. ${ }^{34}$

In the Rawlsian approach - specifically in achieving an overlapping consensusus - the aim is not to have a regulative device, and in particular, it is not at though the principles of justice are adjusted to the claims of the dominant political and social interests. It is important to distinguish between the two stages in justice as fairness, and to be clear that the idea of an overlapping consensus is used only in the second stage. In the first stage, justice as fairness is seen as a free-standing political conception that articulates the values applicable to the special domain of the political, as marked out by the basic structure of the society or the institution under consideration. In the second stage, an account of the stability of justice as fairness is formulated, which provides the basis - in view of the content of its principles and ideals as formulated in the first stage - to generate its own support. In other words, the idea of an overlapping consensus is introduced only in the second stage to explain that despite the plurality of conflicting comprehensive philosophical, economic and moral doctrines, free institutions may gain the allegiance needed to endure over time. ${ }^{35}$

From Rawls's method, it could be argued that rational individuals will adopt two principles for IMF governance, which would be ordered lexicographically. The first principle would state that each country is to have an equal right to a meaningful percentage of total quotas (Westphalian principle) and that population would be a determinant of a certain percentage of the voting power (democracy principle) compatible with the purposes of the IMF. The second principle would have the remaining amount of the quota apportioned among members based on two different sets of variables: (i) those that would reflect a country's economic size and ability to contribute to IMF resources; and (ii) those that would reflect a country's need to borrow IMF resources, which would include external vulnerability and other variables that would capture possible borrowings from the IMF.

These considerations suggest that the IMF should build what Rawls calls an "infrastructure of justice" that ensures every country some reasonable level of voting power and the opportunity to influence decisions, thereby giving it a proper chance to achieve full membership of this global institution. Moreover, the creditor countries should recognize that, whereas they have certain voting powers that come from the weights in the quota formula for the supply of capital variables, such as GDP, the interests of the debtor countries should be taken into account with variables that are the best predictors of future IMF borrowings. When debtor country interests are taken into account and, moreover, the broad mandate of the IMF acknowledged, the argument that safeguarding the use of IMF resources trumps all other

\footnotetext{
${ }^{34}$ Albert Einstein, "Everything should be made as simple as possible but not simpler."

${ }^{35}$ See Rawls (1989).
} 
considerations would be seen to be vacuous. In contrast, original position argumentation requires that the position of the debtors should be the best possible after taking into account the creditors' interests, so that, were the positions to be swapped, the creditors would accept their new position as fair.

\section{Basic Votes}

At the Bretton Woods conference that founded the IMF and World Bank, a compromise was reached between the Westphalian principle of the legal equality of states, which called for one country, one vote, and the economic argument for basing votes solely on capital contributions or capacity to lend to the IMF. The compromise was to allocate 250 "basic votes" to each member country, which meant that every country had a voice because after all each was affected by the institution's regulatory work, even if it did not approach it for conditional loans. The economic argument for the supply of resources to the IMF and the need to safeguard creditor country's interests was reflected in the agreement that countries would have one vote for every US\$100,000 of IMF quota subscribed and, in turn, the quotas took account of the capacity to lend to the IMF. ${ }^{36}$

The balance achieved in this compromise has been lost over time because whereas basic votes have remained unchanged, there has been a 37-fold increase in IMF quotas, which has resulted in a sharp reduction of basic votes as a proportion of the total voting power, and therefore severely reduced the participation of small countries in decision-making. Thus, the basic votes have declined from 11.3 percent to 2.1 percent, and for the original members of the IMF to 0.5 percent. The 0.5 percent is the appropriate measure for the relative decline of the Westphalian principle because the 2.1 percent includes new members, whereas the metric is for one nation, one vote. ${ }^{37}$ The issue of restoration of the basic vote to the original 11.3 percent, or the maximum of 15.8 percent (reached in 1958) is of the utmost importance if the institution is to gain legitimacy, but it is not clear when this issue will be settled in the proposed approach. One reason for this uncertainty is that the current proposals for increasing basic votes span a wide range, with some asking for going as far as the historic high but others suggesting a mere doubling of the basic votes. Another important reason for

\footnotetext{
${ }^{36}$ The basis for calculating voting power - and the role of basic votes - is set out in Article XII, Section 5(a) of the Fund's Articles of Agreement. It provides that "[E] ach member shall have two hundred and fifty votes plus one additional vote for each part of its quota equivalent to one hundred thousand special drawing rights." The two hundred and fifty votes specified in this provision are generally referred to as "basic votes".

${ }^{37}$ Some observers have argued that the relevant point of comparison is 11.3 percent to 2.1 percent rather than to 0.5 percent because even under a pure "one country one vote" principle, the voting share of each country would be diluted with the entry of new members, and that the 0.5 percent for the original members is merely reflecting the fact that, in all elections, the larger the electorate, the smaller the relative weight of each individual's voice. This argument is valid for individual members in an electorate but it does not carry over to the comparison done here, which is not for individual members but between different characteristics (economic size and potential demand and supply for IMF credit, creditor versus debtor interests, Westphalian principle, democracy principle, etc.). Our point is not about what happens to individual members as the group size increases but what would be the appropriate weights for these variables in the quota formulas.
} 
uncertainty is that the restoration of basic votes requires an amendment of the Articles of Agreement, which hinges on the question of the strength of commitment of major shareholders to the timing and implementation of the second stage reforms, but even if commitments were to be made in a time-bound program, the track record is not exactly solid. The membership recalls disappointingly the strong commitment of major shareholders to the Fourth Amendment, which is yet to be ratified a decade after it was approved by the Board of Governors.

There are alternatives to amending the Articles of Agreement, such as adding a constant to the quota formula that gives the equivalent in terms of voting strength from an increase in basic votes, but this would be unfortunate because it would be a backdoor way of addressing the real grievance of the smallest members of the IMF about their voice and representation. As the Rawlsian approach makes abundantly clear, ways to ensure that low income countries (LICs) have adequate opportunity to participate in governance of the institution should be one the top priorities of efforts aimed at enhancing the IMF's legitimacy. The LICs' share in the world economy is small, but the IMF has a far larger role in these economies in terms of policy advice, financing, conditions attached to IMF-supported adjustment programs and the like. The LICs are not effectively represented in the IMF - although the institution is spending a disproportionately larger amount of resources in work on these countries relative to their quota, mainly because of the adjustment programs and the need for more intensive technical assistance. This raises the question of why not have commensurate quotas and voice because addressing the quota problems of LICs would also help in addressing the problem of ownership; if those who design the adjustment programs for the IMF (i.e., staff members) and those who approve the program (i.e., the Executive Directors) included a significant proportion of people whose economies are directly affected by those programs, then this would be a direct way to give meaning to the concept of ownership. ${ }^{38}$ Thus, if there is going to be a new Washington Consensus of best-practice economic policies (e.g., the analytical backdrop for IMF-supported adjustment programs, provision of technical assistance, role of the IMF in LICs), or if the IMF is going to have a bigger role in international surveillance - as envisaged in its medium-term strategy - the countries that are most affected by the these reforms, should also be given the opportunity to provide important inputs in these areas. Such steps to enhance the legitimacy of the IMF would make its conditional financing, international monetary coordination and other roles more credible, thereby potentially shortening financial crises and raising global welfare.

Irrespective of whether the basic votes issue is resolved through the amendment of the Articles of Agreement or through the insertion of a constant in the quota formula, a mechanism for safeguarding the share of basic votes in total voting power should be inserted to safeguard the voting power of small countries and avoid erosion over time as has

\footnotetext{
${ }^{38}$ In the present governance structure, the LICs have an almost negligible proportion of total quotas, which means that in the approval process for IMF-supported adjustment programs, they have virtually no say. With regard to the design of programs, the LICs share of total staff positions in the IMF is also very small, because the staffing is based on merit but it does take into account geographical representation, and there is a positive correlation between IMF quotas and staff positions.
} 
happened over a prolonged period in IMF's history. The option of a mechanism that keeps the ratio of basic votes to total voting power constant as quotas increase (thereby avoiding the need for further amendment of the Articles or a Resolution of the Board of Governors each time an increase is sought) has fortunately garnered welcome support in almost all quarters, including the Resolution of the Board of Governors on the recent ad hoc quota increase. A commitment has been made in the first stage of the IMF reforms to at least double the basic votes and to establish a mechanism that keeps the ratio of basic votes to total voting power constant as quotas increase. The second part of the commitment is welcome, though long overdue, but the first part of the commitment is rather tepid because even a doubling of the basic votes would take the share to 4 percent, which is significantly lower than the 11.3 percent at the inception of the IMF, and it does not seem like the sort of number that would come out of a Rawlsian original position and overlapping consensus.

\section{THE WAY FORWARD}

The issue of voice and representation and its importance for the good governance of the IMF cannot be overemphasized. Unless this issue is addressed in its totality, the risks to the IMF will only increase, including those relating to the perceived weaknesses of the IMF's role in multilateral surveillance and in influencing the policies of advanced countries. There is a need for multilateral consultations to strengthen the surveillance of the world economy, thereby addressing the growing global economic imbalances, which, in turn, would enable its members to address vulnerabilities that affect individual countries and the global financial system. Even more worrisome is the disquieting trend, which could affect the core mission of the IMF and runs the risk of marginalizing the institution, is the huge and rising foreign currency stockpiles in Asia and other developing countries that come at high financial and opportunity costs. These emerging-market countries are self-insuring against future shocks and vulnerabilities through the buildup of reserves, far in excess of the levels required by the fundamentals of their economies. ${ }^{39}$ It is difficult not to draw the implication from this behavior that, in the views of these countries, there are shortcomings in the IMF's role in crisis prevention and resolution. As discussed earlier, the IMF was heavily criticized in Asia for attaching excessive loan conditions on Indonesia and others in the region during the 1997/1998 Asian financial crisis. Some commentators have noted that one reason for the subsequent buildup of reserves in Asia has been to avoid a repeat of such experiences with the IMF. If this trend is not urgently and appropriately addressed through the adaptation of IMF's facilities to the insurance-type need of the membership, and moreover, through voice and quotas reform, it could develop into a core mission risk and jeopardize the relevance of the institution. ${ }^{40}$

${ }^{39}$ If international reserves are held for a rainy day, then some of the emerging market countries must be saving for Noah's Arc, as noted by the former IMF Chief Economist Kenneth Rogoff.

${ }^{40}$ As discussed above, the quotas for many fast-growing market countries are way out of line from their economic weights, and these countries, unhappy about their lack of representation in the IMF Board, have in a way already started leaving the fold of the institution insofar as they have been accumulating vast reserves to markedly lower the probability of any return to the IMF-supported adjustment programs. Furthermore, if these countries conclude that they will not be getting adequate representation and sufficient influence in the IMF, they are likely to continue on the path of larger reserves and even bolstering the regional arrangements such as the

(continued...) 


\section{A. Adjusting Voting Power and Quotas}

The democracy and Westphalian principles should be seen in tandem, with one reinforcing the other. The point can be expressed most clearly in terms of its converse, namely, what are the implications of giving no weight to the democracy principle in the governance structure, but a very large weight to the Westphalian principle? Supposing the share of basic votes were increased not to the 11.3 percent observed at the inception of the IMF, but to a significantly larger number. That would create a tension because the movement along this path would make the governance structure more and more indifferent between, say, Maldives and Palau, on the one hand, and China and India, on the other hand, which would not meet Rawls's test. In this regard, as the concerns relating to the Westphalian principle are addressed - for example, the commitment made in the first stage of the current IMF reform package - it becomes all the more important to address the democracy deficit and incorporate the population variable either in the quota formula, or alternatively, institute two classes of basic votes, one based on the Westphalian principle and the other based on the democracy deficit or population principle. Such an approach, undoubtedly, would not only pass Rawls's test, but one can say with confidence that it would be seen by the majority of countries as a major step in the right direction in improving the governance structure of the IMF. The following table on basic votes and variables for the quota formula is set up according to the idea of two types of basic votes, but it should be reiterated that the listed variables and voting shares are for heuristic purposes and not a specific proposal. Indeed, our view is that the basic votes should be much larger than 4 percent, but we decided to start the range at that low level because that is the minimum commitment in the recent Resolution of the Board of Governors.

The main message to deduce from the table, or from this paper, is that instead of deciding arbitrarily (and by just one man, former US Treasury Secretary White) what the voting shares of each country should be in the IMF, and then come up with a formula that delivers those numbers, the trustees are to visualize themselves in the Rawlsian original position. Whereas they are all self-interested rational persons motivated to select whatever seems advantageous for their countries, but, because they stand behind the veil of ignorance, they will decide in an informed and enlightened way. There are many different concepts of the IMF that the trustees in the original position could design, but the important point is that since they do not know what their country is in the real world, they should be prepared to end up representing anyone.

Therefore, each trustee would want to pick the one IMF that offers the least bad alternative, meaning, they will pick the IMF with the least fortunate country in the least unfortunate situation. In particular, a self-interested rational person would not want to belong to an institution in which the least fortunate, who in fact is most affected by the workings of the

Chiang Mai Initiative in east Asia, which is an ambitious effort to create a regional financing facility, including a network of currency swap lines launched by the ASEAN+3 group in 2000 . 
Table 1. Basic Votes and Variables for Quota Formulas

\begin{tabular}{lc}
\hline & Percentage votes \\
\hline Basic vote I & $4-15$ \\
Basic vote II & Westphalian Principle \\
& \\
Variables for the Quota Formula & \\
(Supply and demand for IMF resources) & \\
& \\
Supply Variables & \\
PPP-Based GDP & \\
International reserves & \\
& \\
Demand Variables & \\
Current payments or receipts and capital flows & \\
Variability of current receipts and capital flows \\
Past IMF-supported programs \\
Capital flows/GDP \\
Subinvestment grade credit rating \\
Sovereign bond spreads \\
Reserves/short-term debt \\
Reserves/financing gap \\
Reserves/monetary base \\
\hline
\end{tabular}

institution, ends up with the least voting power. For this reason, before a decision is made about what variables to insert in the quota formula, there should be a broad agreement about what the voting shares ought to be for the Westphalian and democracy principles, as well as the demand and supply variables. An agreement on the shares for the demand and supply variables will be an important step in ensuring that the interests of debtors and creditors are adequately taken into account in the overlapping consensus.

Among the supply variables, we have put PPP-based GDP for the reasons given in the earlier section of this paper. We are aware, however, of the suggestion that a weighted average of the PPP- and market-exchange rate-GDP could be used in the spirit of a compromise. In our view, the first best option would be to agree on what is the right metric for the supply of resources behind the veil of ignorance, and, as pointed out earlier, it is hard to perceive why PPP-based GDP would not be chosen, but we stand ready to be corrected. The other supply variable is international reserves, although this variable could also have been put among the demand variables because it serves both purposes. This has been done just for ease of presentation, but one should not belabor this point because it is clear that the GDP variable would take up the bulk of the weight in the supply variable. Alternatively, one could include 
international reserves in the demand and supply variables just to emphasize that it is a determinant of both variables, but in any event, the weight of the sum of these two variables would simply be equal to the weight given to the reserves variable when shown only in the demand side.

Among the demand variables, those in the current quota formulas (openness and export variability) are included, but needless to say, they could be dropped altogether or could be given low weight because the other (new) demand variables are superior predictors of the use of IMF resources. The new demand variables included in the table are: those that capture past use of IMF resources; subinvestment grade credit rating; sovereign bond spreads; reserves/short term debt; reserves/financing gap; reserves/monetary base. Although these new variables are good predictors of the demand for IMF resources, there is correlation amongst them. As noted earlier, one approach would be to work with a subset of these variables with the lowest correlation. An alternative approach would be to use most or all of these variables, but assign low weights to the individual ones. Yet another approach would be to use a hybrid variable, which uses information from each to construct a new variable; this approach would also take care of the problem of the missing data in some countries.

Some observers have noted that a couple of the variables that have been included in the demand side suffer from the problem of moral hazard, namely, there is a problem of hidden action which leads to increased likelihood of undesirable outcomes: countries will be rewarded with higher quotas if they pursue policies that increase their economic vulnerabilities, which cause lower credit ratings, higher sovereign bond spreads, etc.. The answer to this charge is that whereas it should be recognized that moral hazard exists and it can be an important consideration in some policy measures, it should not be oversold. In those situations such as when banks (or governments) are shielded from the consequences of their actions and take imprudent risks because of expectations of bail outs, policymakers must devise ways of dealing with this problem. However, it is hard to understand how this might be a problem in the present context, namely, that governments will implement risky policies because even when things go wrong, they benefit from a higher IMF quota. As argued in this paper, IMF quotas are important, but it is certainly not the case that they are like so totally important as to cause negative incentive effects in the implementation of financial policies. In any event, the moral hazard argument would also apply to the traditional variables such as international reserves because countries that self-insure (e.g., have higher international reserve holdings) will have a lower need for IMF-supported adjustment programs. In other words, to the extent that they are less likely to borrow from the IMF because of a greater ability to respond to external shocks, this would be reflected in a lower quota. To the contrary, it could be argued that international reserves should be given a higher weight in the quota formula because this variable is a determinant of a country's ability to provide resources to the IMF, which is the traditional view, but it is also a determinant of the need for borrowing because a country that is subjected to terms of trade and other external shocks will also hold higher reserves, ceteris paribus.

\section{B. Aligning Quotas and Basic Votes with Justice as Fairness}

It might be argued that Rawls' principles are easier to apply abstractly in a general setting than to specific complex circumstances, such as the IMF governance structure. In particular, 
we cannot know for sure what quota formulas would be chosen by rational actors in the original position. However, this should not stop us from doing our best to imagine what the outcome of an original position negotiation might be, even while recognizing that reasonable people can disagree. The issue of IMF quota formulas seems particularly complicated, because the political reality is that, if certain principles of democratic equality (one nation one vote or one person one vote) are pressed too far, the countries with strong economic power will simply refuse to be part of the arrangement. Indeed, one could argue that the industrial countries will never agree to any formula that is "fair" in the Rawlsian sense. More generally, as noted earlier, there is a high probability that the industrial countries will not be borrowers, but this does not mean that the IMF should follow the Golden Rule: "whoever has the gold makes the rules." As mentioned earlier in the paper, the IMF is not a mere lending institution; its remit is far broader than what some observers claim to be the case, and this broad mandate is here to stay. Also, developing countries are creditors in the IMF as well, and moreover, they would like to have a larger role as creditors.

Another point that bears emphasis and one that is of particular importance in the original position is the question of how much deviation from pure democratic principles would be acceptable in order to secure participation of all countries. This is analogous to the widespread debate in political/economic/philosophical circles concerning how much economic inequality would be allowable in a society deemed just via Rawlsian principles. Rawls theoretically allowed for such inequality because it is conceivable that the least well off could, nevertheless, have more absolute wealth if the economy allowed for the entrepreneurial incentives that create winners and losers. Of course, stating this theoretically doesn't resolve the debate about how much inequality is acceptable. In effect, liberals and conservatives debate this question endlessly. That said, it is much easier to demonstrate what does not satisfy Rawlsian principles than what does, and that has been a major aim of this paper. The quota formulas and the governance structure prevailing at present in the IMF do not come close to justice as fairness.

We wish to emphasize that we are not trying to downplay what economists would call efficiency criteria (does this contribute toward the furtherance of the IMF's goals, and does it do so at low cost?) because surely these considerations should be given appropriate weights when designing quota formulas and the governance structure. In fact, we have argued that even these efficiency criteria are not always met in the IMF's governance structure, such as the mixed industrial/developing country constituencies in the Executive Board, the special majorities required for certain decisions, and the selection of the management team. With regard to the quota formulas, the efficiency considerations are taken up in the debate on the appropriate variables for measuring a member's ability to contribute to the IMF's financial base (e.g., GDP converted to a common base at market exchange rates versus the alternative PPP-based measure of GDP, openness variables versus international reserve holdings). Put differently, the aim has not been to emphasize equity criteria over efficiency criteria, but rather to point out that Rawls's framework provides important insights for judging competing proposals.

A number of important issues relevant to the revamping of the quota formulas and basic votes have been identified and recognized for quite some time but remain unresolved. 
Despite the claims of some who view the IMF as a financial institution, with little or no implications for global governance, the IMF is sui generis, never was and it is impossible to envisage it as being transformed into a narrowly defined monetary institution. For example, the IMF has developed a number of elaborate reporting systems for member countries, including the Financial Sector Stability Assessments (FSSA) to report on the member countries' financial sectors and the Reports on the Observance of Standards and Codes (ROSC) to assess their adherence to certain standards. These reports are important to the IMF's surveillance activities, as are the bi-annual World Economic Outlook (WEO), the Global Financial Stability Report (GFSR), and most importantly, the annual Article IV consultations with members. The surveillance activities take up more than one-quarter of the IMF's administrative budget. Since the IMF produces public goods that are not subject to market discipline or even have a price attached to them, how can it possibly be engaged in mere financial transactions and be narrowly defined as a pure financial institution?

At the risk of repetition, we wish to stress that since quotas serve multiple purposes, the quota formulas have to necessarily balance sometimes competing considerations, and it can be argued that they are overburdened. Moreover, whereas the different roles of quotas provide guidance as to the variables that should enter the quota formulas, it is unfortunately true that several of the traditional variables do not meet the efficiency criteria of being the best proxy for the characteristic that the formulas are trying to capture. In particular, the demand variables that reflect a member's potential need to borrow from the IMF have severe shortcomings. At the same time, there has been an unfortunate tendency to focus on a member's ability to contribute usable resources to the IMF, but as noted earlier, the supply of credit to the IMF is not a market clearing phenomenon. A large number of countries would be more than willing to provide all the resources needed by the institution, and indeed many small groups of developing countries can meet the financing requirements without any difficulty. Therefore, the argument that the use of quotas as a basis for calculating voting power derives from the role of quotas in determining the amount of a member's financial contribution to the IMF is misleading. There is little basis for arguing that many decisions taken by the IMF relate directly to how its financial resources are used, and hence voting power should be linked to members' roles as contributors of financial resources. The more important consideration is that quotas should determine voting power in relation to the IMF's broader responsibilities, including bilateral and multilateral surveillance, as well as capacity building, and the institution would be better equipped to discharge these broader responsibilities if there were to be the active engagement of all its members. The argument that there is a close link between these activities and IMF financing is not very convincing. For example, the point that effective surveillance will reduce the risk that members will demand IMF financial resources is stretching the point quite a bit because that demand depends on many things other than policy slippages.

The selection of variables in the quota formulas is a challenging task but one would expect that they should capture, at a minimum, a member's capacity to contribute financial resources to the IMF and the potential need to use its resources; we set aside for the moment the broader issues that were stressed above, including the Westphalian and democratic principles. Regarding the capacity to contribute financial resources, we have pointed out that GDP converted at market exchange rates should not be viewed as the more relevant measure 
of a member's ability to contribute resources, because the argument that it reflects the international market value of resources generated by an economy misses the point that there will never be a need to convert nontraded goods and services at market exchange rates to pay for IMF quotas. Quotas are a small fraction of GDP or exports and one cannot imagine an IMF that would be so large that countries will become strapped for cash and have to sell nontradables to pay for their quotas. Therefore, PPP-based GDP is the more relevant indicator for measuring potential contributions to the IMF because the larger the volume of goods and services produced by an economy, the greater its size and role in the world economy. In this respect, since the quota formulas are based on GDP converted at market exchange rates, the supply variable is barking up the wrong tree. It may be worth emphasizing that the two different measures of GDP make a big difference in the calculations of quotas: the share in global totals of advanced economies of GDP converted at market exchange rates is over $3 / 4^{\text {th }}$ of the global total but declines to about $1 / 2$ for PPP-based GDP. The situation with the demand variables is worse. The openness variable is based on the argument that relatively more open economies are more vulnerable to external shocks, and therefore will be more likely to use IMF resources. Thus, openness enters the quota formulas through the current receipts and payments (both separately and combined), as well as through the ratio of current receipts to GDP as a multiplicative factor (in three of the five formulas), which means that it plays a major role in the calculated quotas. The biggest irony is that the advanced economies have 70 percent of the share in global totals of current payments and receipts, which means that the bulk of the share in calculated quotas from the demand variable is eaten up by the countries that have not borrowed in decades and are not expected to borrow in the foreseeable future. Variability of current receipts, which is the other demand variable in the quota formulas, is not much better because the advanced economies share is over 60 percent. If these variables are supposedly capturing the demand for IMF resources, then why is it that their correlation with actual use of IMF resources has been on a downward path toward zero when calculated with rolling windows over the last thirty years. The bottom line is that it is high time to look for new demand variables in the quota formulas, and the variables discussed in Table 1 would appear to be prime candidates. In particular, the traditional openness and variability variables in the quota formulas need to be replaced with new variables that have at least some correlation with actual use of IMF resources.

The IMF is a unique organization and one of the most important characteristic of this uniqueness is that its members have invested a part of their individual economic sovereignty into the IMF's surveillance activities. Furthermore, the institution has global economic and financial rule-making powers that are not replicated in any other international organization. In turn, the IMF is charged with the responsibility of crisis prevention and resolution, and the greatest risk to the membership would arise if the IMF were unable to perform as expected. In short, the IMF is sui generis, but unfortunately, it is sometimes not seen as such, and some have advocated a narrowly defined institution, which does some so-called mere financial activities, thereby remaining outside the sphere of global governance. However, the image or conception of the IMF as a purely monetary institution is false and misleading, if for no other reason than simply because that has not been the case in the particular, concrete sense that has been the IMF. In this regard, the dichotomy between the narrow financial institution and the broader institution, with the latter being an important element of global governance through its surveillance and regulatory activities, is particularly troublesome. Rather than 
posing the problem as a choice between two competing conceptions of the IMF, as proponents of the narrow view do, we should recognize that the IMF that is out there (in the particular, concrete sense of its history and future prospects) has a broad mandate to a greater or lesser degree.

Opponents of this view might respond that it is still worthwhile to draw a distinction between the two views as ideals, and moreover, work towards narrowing that mandate to a pure financial institution. Yet, even as an ideal, this dichotomy is really only a less thoroughly or more lightly defined mandate for the IMF. For how else can an institution that has the mandate to provide conditional liquidity that impacts directly on the formulation and implementation of macroeconomic and structural policies, or has important regulatory and supervisory powers, avoid global governance issues. We are dealing with a continuum, not a dichotomy. Somewhere between the impossibly pure monetary institution and the institution so completely encumbered with a broad mandate that it is unable to engage in core activities lies the properly mandated IMF, which is capable of focusing on the critical work program and delivering its output, without ignoring or disavowing what it owes to the international community in terms of that incalculably precious endowment that member countries have given it, that is, some of their economic sovereignty. Locating the space in which a properly constituted IMF can work is vital to the future effectiveness of the institution, and should be a central concern of all those who advocate good governance, representatives from industrial and developing countries alike. A number of proposals, including those discussed in this paper, have been put on the table, and if IMF officials wish to pursue the medium-term strategy that calls for a more focused IMF, they will need to do more than focus on efficiency gains; they must strive for justice and fairness as well. It should be accepted that the IMF is not just a purely financial institution, and an institution that is not seen as fair cannot prove stable nor can it have the general support to carry out an ambitious mandate. For this and other reasons discussed in the paper, it should be clear that the institutional governance paradigm requires a special approach, and since one is dealing with a unique/complex organization, the paradigm has to be specifically tailored to the circumstances.

\section{Conclusion}

There is no disagreement that a major strength of the IMF is that it is a cooperative institution-bringing together 184 countries with diverse conditions and needs - that has provided some of the most valuable public goods available to the international community, nor is one challenging the account that some efforts have been made to assure members that their voice is heard and that they have an appropriate weight in decision-making. However, these efforts are insufficient and much remains to be done. Legitimate concerns have been raised on the voice and quotas issue in various parts of the developing-country membership and, unless comprehensive solutions are found, it should be clear that the IMF quotas will remain a contested terrain, both within the IMF and in the public domain. Developing countries have long pushed for changes in the IMF's voting structure to better reflect their international economic weight and to give a stronger voice and representation to LICs, arguing that the current system undermines the legitimacy of the institution. There is the concern that unless the matter is addressed, some developing countries, especially in Asia, would start moving away from the IMF's fold. 
The Rawlsian approach suggests a more fundamental review of the governance issue than is implied from the state of the discussion in the Executive Board. Some areas of quota and voice reform that require a good deal of further work are either not discussed or presented by the IMF staff in such a way as if the discussions are in the final stages, namely, the selection of variables for a new quota formula - in particular, the possibility of using purchasing power parity rather than market exchange rates to derive GDP receives only a cursory mentionand possible other variables for external volatility and demand for IMF resources are not discussed at all. Suffice it to say that the quota formulas require a major rethink, and it does not make much sense to confine the discussion by imposing unreasonably tight boundaries. There is also the concern that once the current already protracted reform effort is completed without fundamental corrections, some countries will say that now we are done with the reform and we don't have to go back to this subject for several decades. Recall that the utterly flawed Bretton Woods formula has been with us for over six decades.

Justice as fairness is - to use the IMF's own language - a continuous performance criterion that must be observed by all those who would strive for a well-functioning IMF. The method that Rawls developed in A Theory of Justice (1999) and refined in numerous other publications of postulating an original position - a hypothetical situation in which individuals behind a veil of ignorance decide to agree on principles of social cooperation - and the work on overlapping consensus that is discussed in detail in Political Deliberation (1996) provide a framework for overcoming the impasse on the quota formulas. Giving voice to just principles is a sine qua non, and this requires the willingness to pay the costs necessary for their realization, which means reaching an acceptable outcome that will no doubt require tough political decisions by the IMF's major shareholders. As Rawls puts it in the famous last sentence of his first book, "[p]urity of heart, if one could attain it, would be to see clearly and to act with grace and self-command from this point of view." 


\section{APPENDIX}

Table A1. Formulas Used for Quota Calculations: 2006 Update 1/

\begin{tabular}{|c|c|c|c|c|}
\hline Country & $\begin{array}{c}\text { Formula(s) Picked by Decision } \\
\text { Rule } 2 /\end{array}$ & $\begin{array}{l}\text { Actual Quotas } \\
1 / \text { (In million of } \\
\text { SDRs) }\end{array}$ & $\begin{array}{l}\text { Actual Quotas } \\
\text { Shares }\end{array}$ & $\begin{array}{l}\text { Calculated } \\
\text { Quotas }\end{array}$ \\
\hline Afghanistan & Schemes III and M4 & 161.90 & 0.076 & 0.042 \\
\hline Albania & Schemes III and IV & 48.70 & 0.023 & 0.026 \\
\hline Algeria & Schemes III and IV & 1254.70 & 0.587 & 0.325 \\
\hline Angola & Schemes III and M4 & 286.30 & 0.134 & 0.193 \\
\hline Antigua and Barbuda & Schemes M4 and M7 & 13.50 & 0.006 & 0.006 \\
\hline Argentina & Schemes III and IV & 2117.10 & 0.991 & 0.396 \\
\hline Armenia & Schemes M4 and III & 92.00 & 0.043 & 0.012 \\
\hline Australia & Bretton Woods & 3236.40 & 1.514 & 1.182 \\
\hline Austria & Bretton Woods & 1872.30 & 0.876 & 1.142 \\
\hline Azerbaijan & Schemes M4 and M7 & 160.90 & 0.075 & 0.036 \\
\hline Bahamas, The & Schemes M4 and M7 & 130.30 & 0.061 & 0.029 \\
\hline Bahrain & Schemes M4 and M7 & 135.00 & 0.063 & 0.144 \\
\hline Bangladesh & Bretton Woods & 533.30 & 0.250 & 0.103 \\
\hline Barbados & Bretton Woods & 67.50 & 0.032 & 0.015 \\
\hline Belarus & Schemes M4 and M7 & 386.40 & 0.181 & 0.118 \\
\hline Belgium & Bretton Woods & 4605.20 & 2.155 & 2.088 \\
\hline Belize & Bretton Woods & 18.80 & 0.009 & 0.006 \\
\hline Benin & Bretton Woods & 61.90 & 0.029 & 0.009 \\
\hline Bhutan & Schemes III and M4 & 6.30 & 0.003 & 0.004 \\
\hline Bolivia & Schemes IV and III & 171.50 & 0.080 & 0.023 \\
\hline Bosnia-Herzegovina & Schemes M4 and M7 & 169.10 & 0.079 & 0.066 \\
\hline Botswana & Schemes III and M4 & 63.00 & 0.029 & 0.054 \\
\hline Brazil & Bretton Woods & 3036.10 & 1.421 & 0.998 \\
\hline Brunei Darussalam & Schemes M4 and M7 & 215.20 & 0.101 & 0.058 \\
\hline Bulgaria & Schemes M4 and M7 & 640.20 & 0.300 & 0.113 \\
\hline Burkina Faso & Schemes III and IV & 60.20 & 0.028 & 0.010 \\
\hline Burundi & Schemes III and M4 & 77.00 & 0.036 & 0.003 \\
\hline Cambodia & Schemes M4 and III & 87.50 & 0.041 & 0.055 \\
\hline Cameroon & Bretton Woods & 185.70 & 0.087 & 0.033 \\
\hline Canada & Schemes M7 and IV & 6369.20 & 2.980 & 3.098 \\
\hline Cape Verde & Bretton Woods & 9.60 & 0.004 & 0.004 \\
\hline Central African Republic & Schemes III and IV & 55.70 & 0.026 & 0.004 \\
\hline Chad & Schemes III and M4 & 56.00 & 0.026 & 0.016 \\
\hline Chile & Schemes III and IV & 856.10 & 0.401 & 0.298 \\
\hline China & Bretton Woods & 6369.20 & 2.980 & 5.197 \\
\hline Colombia & Bretton Woods & 774.00 & 0.362 & 0.208 \\
\hline
\end{tabular}




\begin{tabular}{|c|c|c|c|c|}
\hline Country & $\begin{array}{l}\text { Formula(s) Picked by Decision } \\
\text { Rule } 2 /\end{array}$ & $\begin{array}{l}\text { Actual Quotas } \\
1 / \text { (In million of } \\
\text { SDRs) }\end{array}$ & $\begin{array}{l}\text { Actual Quotas } \\
\text { Shares }\end{array}$ & $\begin{array}{l}\text { Calculated } \\
\text { Quotas }\end{array}$ \\
\hline Comoros & Schemes III and IV & 8.90 & 0.004 & 0.001 \\
\hline Congo, Dem. Republic of & Schemes III and M4 & 533.00 & 0.249 & 0.025 \\
\hline Congo, Republic of & Schemes III and M4 & 84.60 & 0.040 & 0.029 \\
\hline Costa Rica & Schemes M4 and M7 & 164.10 & 0.077 & 0.084 \\
\hline Cote d'Ivoire & Schemes III and M4 & 325.20 & 0.152 & 0.061 \\
\hline Croatia & Bretton Woods & 365.10 & 0.171 & 0.144 \\
\hline Cyprus & Bretton Woods & 139.60 & 0.065 & 0.061 \\
\hline Czech Republic & Bretton Woods & 819.30 & 0.383 & 0.538 \\
\hline Denmark & Schemes III and M4 & 1642.80 & 0.769 & 1.078 \\
\hline Djibouti & Bretton Woods & 15.90 & 0.007 & 0.003 \\
\hline Dominica & Bretton Woods & 8.20 & 0.004 & 0.002 \\
\hline Dominican Republic & Schemes M4 and M7 & 218.90 & 0.102 & 0.085 \\
\hline Ecuador & IV and M7 & 302.30 & 0.141 & 0.078 \\
\hline Egypt & Schemes III and IV & 943.70 & 0.442 & 0.248 \\
\hline El Salvador & Schemes III and M4 & 171.30 & 0.080 & 0.053 \\
\hline Equatorial Guinea & Schemes M4 and M7 & 32.60 & 0.015 & 0.039 \\
\hline Eritrea & Schemes M4 and M7 & 15.90 & 0.007 & 0.008 \\
\hline Estonia & Bretton Woods & 65.20 & 0.031 & 0.067 \\
\hline Ethiopia & Schemes III and M4 & 133.70 & 0.063 & 0.076 \\
\hline Fiji & Schemes III and M4 & 70.30 & 0.033 & 0.011 \\
\hline Finland & Schemes M7 and IV & 1263.80 & 0.591 & 0.546 \\
\hline France & Bretton Woods & 10738.50 & 5.025 & 4.334 \\
\hline Gabon & Schemes III and M4 & 154.30 & 0.072 & 0.047 \\
\hline Gambia, The & Bretton Woods & 31.10 & 0.015 & 0.003 \\
\hline Georgia & Schemes M4 and III & 150.30 & 0.070 & 0.017 \\
\hline Germany & Bretton Woods & 13008.20 & 6.087 & 6.953 \\
\hline Ghana & Schemes M4 and III & 369.00 & 0.173 & 0.043 \\
\hline Greece & Bretton Woods & 823.00 & 0.385 & 0.456 \\
\hline Grenada & Bretton Woods & 11.70 & 0.005 & 0.003 \\
\hline Guatemala & Bretton Woods & 210.20 & 0.098 & 0.065 \\
\hline Guinea & Schemes III and IV & 107.10 & 0.050 & 0.010 \\
\hline Guinea-Bissau & Schemes III and M4 & 14.20 & 0.007 & 0.004 \\
\hline Guyana & Schemes M4 and M7 & 90.90 & 0.043 & 0.015 \\
\hline Haiti & Schemes III and M4 & 81.90 & 0.038 & 0.014 \\
\hline Honduras & Bretton Woods & 129.50 & 0.061 & 0.037 \\
\hline Hungary & Bretton Woods & 1038.40 & 0.486 & 0.468 \\
\hline Iceland & Bretton Woods & 117.60 & 0.055 & 0.035 \\
\hline India & Bretton Woods & 4158.20 & 1.946 & 1.200 \\
\hline Indonesia & Schemes III and IV & 2079.30 & 0.973 & 0.767 \\
\hline Iran & Schemes III and IV & 1497.20 & 0.701 & 0.404 \\
\hline Iraq & Schemes M4 and III & 1188.40 & 0.556 & 0.246 \\
\hline Ireland & Bretton Woods & 838.40 & 0.392 & 1.677 \\
\hline
\end{tabular}




\begin{tabular}{|c|c|c|c|c|}
\hline Country & $\begin{array}{c}\text { Formula(s) Picked by Decision } \\
\text { Rule 2/ }\end{array}$ & $\begin{array}{l}\text { Actual Quotas } \\
1 / \text { (In million of } \\
\text { SDRs) }\end{array}$ & $\begin{array}{l}\text { Actual Quotas } \\
\text { Shares }\end{array}$ & $\begin{array}{l}\text { Calculated } \\
\text { Quotas }\end{array}$ \\
\hline Israel & Schemes M4 and III & 928.20 & 0.434 & 0.579 \\
\hline Italy & Bretton Woods & 7055.50 & 3.301 & 3.442 \\
\hline Jamaica & Bretton Woods & 273.50 & 0.128 & 0.051 \\
\hline Japan & Bretton Woods & 13312.80 & 6.229 & 7.525 \\
\hline Jordan & Bretton Woods & 170.50 & 0.080 & 0.082 \\
\hline Kazakhstan & Schemes III and M4 & 365.70 & 0.171 & 0.164 \\
\hline Kenya & Bretton Woods & 271.40 & 0.127 & 0.036 \\
\hline Kiribati & Bretton Woods & 5.60 & 0.003 & 0.003 \\
\hline Korea & Schemes III and M4 & 1633.60 & 0.764 & 2.508 \\
\hline Kuwait & Schemes III and M4 & 1381.10 & 0.646 & 0.351 \\
\hline Kyrgyz Republic & Schemes III and M4 & 88.80 & 0.042 & 0.010 \\
\hline Lao, People's Dem. Rep. & Bretton Woods & 52.90 & 0.025 & 0.006 \\
\hline Latvia & Schemes M4 and M7 & 126.80 & 0.059 & 0.053 \\
\hline Lebanon & Schemes III and M4 & 203.00 & 0.095 & 0.176 \\
\hline Lesotho & Schemes M4 and M7 & 34.90 & 0.016 & 0.012 \\
\hline Liberia & Bretton Woods & 129.20 & 0.060 & 0.005 \\
\hline Libya & Schemes III and M4 & 1123.70 & 0.526 & 0.228 \\
\hline Lithuania & Schemes III and M4 & 144.20 & 0.067 & 0.096 \\
\hline Luxembourg & Bretton Woods & 279.10 & 0.131 & 1.375 \\
\hline Macedonia, FYR & Schemes M4 and III & 68.90 & 0.032 & 0.028 \\
\hline Madagascar & Schemes III and M4 & 122.20 & 0.057 & 0.022 \\
\hline Malawi & Schemes M7 and M4 & 69.40 & 0.032 & 0.007 \\
\hline Malaysia & Bretton Woods & 1486.60 & 0.696 & 1.399 \\
\hline Maldives & Bretton Woods & 8.20 & 0.004 & 0.006 \\
\hline Mali & Schemes III and IV & 93.30 & 0.044 & 0.015 \\
\hline Malta & Bretton Woods & 102.00 & 0.048 & 0.058 \\
\hline Marshall Islands & Schemes M4 and M7 & 3.50 & 0.002 & 0.001 \\
\hline Mauritania & Schemes M4 and M7 & 64.40 & 0.030 & 0.008 \\
\hline Mauritius & Schemes M4 and M7 & 101.60 & 0.048 & 0.032 \\
\hline Mexico & Schemes IV and III & 2585.80 & 1.210 & 1.928 \\
\hline Micronesia, Fed. States of & Schemes M4 and M7 & 5.10 & 0.002 & 0.002 \\
\hline Moldova & Schemes M4 and M7 & 123.20 & 0.058 & 0.018 \\
\hline Mongolia & Bretton Woods & 51.10 & 0.024 & 0.010 \\
\hline Morocco & Bretton Woods & 588.20 & 0.275 & 0.165 \\
\hline Mozambique & Schemes III and M4 & 113.60 & 0.053 & 0.025 \\
\hline Myanmar & Schemes III and IV & 258.40 & 0.121 & 0.032 \\
\hline Namibia & Schemes III and M4 & 136.50 & 0.064 & 0.024 \\
\hline Nepal & Schemes III and IV & 71.30 & 0.033 & 0.021 \\
\hline Netherlands & Bretton Woods & 5162.40 & 2.416 & 2.880 \\
\hline New Zealand & Bretton Woods & 894.60 & 0.419 & 0.229 \\
\hline Nicaragua & Bretton Woods & 130.00 & 0.061 & 0.021 \\
\hline Niger & Schemes III and IV & 65.80 & 0.031 & 0.007 \\
\hline
\end{tabular}




\begin{tabular}{|c|c|c|c|c|}
\hline Country & $\begin{array}{l}\text { Formula(s) Picked by Decision } \\
\text { Rule } 2 /\end{array}$ & $\begin{array}{l}\text { Actual Quotas } \\
1 / \text { (In million of } \\
\text { SDRs) }\end{array}$ & $\begin{array}{l}\text { Actual Quotas } \\
\text { Shares }\end{array}$ & $\begin{array}{l}\text { Calculated } \\
\text { Quotas }\end{array}$ \\
\hline Nigeria & Schemes III and M4 & 1753.20 & 0.820 & 0.309 \\
\hline Norway & Schemes III and IV & 1671.70 & 0.782 & 0.868 \\
\hline Oman & Schemes III and M4 & 194.00 & 0.091 & 0.150 \\
\hline Pakistan & Bretton Woods & 1033.70 & 0.484 & 0.191 \\
\hline Palau, Republic of & Schemes M4 and M7 & 3.10 & 0.001 & 0.002 \\
\hline Panama & Schemes M7 and M4 & 206.60 & 0.097 & 0.049 \\
\hline Papua New Guinea & Schemes M4 and III & 131.60 & 0.062 & 0.028 \\
\hline Paraguay & Schemes III and M4 & 99.90 & 0.047 & 0.039 \\
\hline Peru & Bretton Woods & 638.40 & 0.299 & 0.139 \\
\hline Philippines & Schemes M4 and M7 & 879.90 & 0.412 & 0.504 \\
\hline Poland & Schemes III and IV & 1369.00 & 0.641 & 0.739 \\
\hline Portugal & Schemes M7 and M4 & 867.40 & 0.406 & 0.528 \\
\hline Qatar & Schemes III and M4 & 263.80 & 0.123 & 0.134 \\
\hline Romania & Schemes IV and III & 1030.20 & 0.482 & 0.207 \\
\hline Russia & Schemes III and IV & 5945.40 & 2.782 & 1.519 \\
\hline Rwanda & Schemes III and IV & 80.10 & 0.037 & 0.007 \\
\hline Samoa & Schemes M4 and III & 11.60 & 0.005 & 0.002 \\
\hline San Marino & Bretton Woods & 17.00 & 0.008 & 0.024 \\
\hline Sao Tome and Principe & Schemes M4 and M7 & 7.40 & 0.003 & 0.001 \\
\hline Saudi Arabia & Schemes III and M4 & 6985.50 & 3.269 & 1.063 \\
\hline Senegal & Schemes III and IV & 161.80 & 0.076 & 0.024 \\
\hline Serbia, Republic of & Schemes III and M4 & 467.70 & 0.219 & 0.111 \\
\hline Seychelles & Bretton Woods & 8.80 & 0.004 & 0.005 \\
\hline Sierra Leone & Schemes III and M4 & 103.70 & 0.049 & 0.004 \\
\hline Singapore & Bretton Woods & 862.50 & 0.404 & 1.922 \\
\hline Slovak Republic & Schemes M4 and M7 & 357.50 & 0.167 & 0.231 \\
\hline Slovenia & Bretton Woods & 231.70 & 0.108 & 0.144 \\
\hline Solomon Islands & Schemes M4 and III & 10.40 & 0.005 & 0.003 \\
\hline Somalia & Bretton Woods & 81.70 & 0.038 & 0.002 \\
\hline South Africa & Bretton Woods & 1868.50 & 0.874 & 0.436 \\
\hline Spain & Bretton Woods & 3048.90 & 1.427 & 2.250 \\
\hline Sri Lanka & Schemes M7 and M4 & 413.40 & 0.193 & 0.074 \\
\hline St. Kitts and Nevis & Bretton Woods & 8.90 & 0.004 & 0.003 \\
\hline St. Lucia & Bretton Woods & 15.30 & 0.007 & 0.004 \\
\hline St. Vincent \& Grenadines & Bretton Woods & 8.30 & 0.004 & 0.002 \\
\hline Sudan & Bretton Woods & 315.10 & 0.147 & 0.040 \\
\hline Suriname & Schemes M4 and III & 92.10 & 0.043 & 0.009 \\
\hline Swaziland & Bretton Woods & 50.70 & 0.024 & 0.021 \\
\hline Sweden & Schemes M7 and M4 & 2395.50 & 1.121 & 1.229 \\
\hline Switzerland & Schemes M7 and M4 & 3458.50 & 1.618 & 1.530 \\
\hline Syrian Arab Republic & Bretton Woods & 293.60 & 0.137 & 0.122 \\
\hline Tajikistan & Schemes M4 and M7 & 87.00 & 0.041 & 0.012 \\
\hline
\end{tabular}




\begin{tabular}{|c|c|c|c|c|}
\hline Country & $\begin{array}{l}\text { Formula(s) Picked by Decision } \\
\text { Rule } 2 /\end{array}$ & $\begin{array}{l}\text { Actual Quotas } \\
1 / \text { (In million of } \\
\text { SDRs) }\end{array}$ & $\begin{array}{l}\text { Actual Quotas } \\
\text { Shares }\end{array}$ & $\begin{array}{l}\text { Calculated } \\
\text { Quotas }\end{array}$ \\
\hline Tanzania & Schemes III and IV & 198.90 & 0.093 & 0.033 \\
\hline Thailand & Schemes M4 and M7 & 1081.90 & 0.506 & 0.909 \\
\hline Timor-Leste & Schemes M4 and M7 & 8.20 & 0.004 & 0.006 \\
\hline Togo & Schemes M4 and III & 73.40 & 0.034 & 0.009 \\
\hline Tonga & Schemes M4 and M7 & 6.90 & 0.003 & 0.001 \\
\hline Trinidad and Tobago & Schemes III and M4 & 335.60 & 0.157 & 0.062 \\
\hline Tunisia & Bretton Woods & 286.50 & 0.134 & 0.105 \\
\hline Turkey & Schemes III and IV & 964.00 & 0.451 & 0.741 \\
\hline Turkmenistan & Schemes III and IV & 75.20 & 0.035 & 0.046 \\
\hline Uganda & Schemes III and IV & 180.50 & 0.084 & 0.025 \\
\hline Ukraine & Schemes III and M4 & 1372.00 & 0.642 & 0.277 \\
\hline United Arab Emirates & Schemes III and M4 & 611.70 & 0.286 & 0.461 \\
\hline United Kingdom & Bretton Woods & 10738.50 & 5.025 & 5.176 \\
\hline United States & Bretton Woods & 37149.30 & 17.382 & 16.795 \\
\hline Uruguay & Schemes III and IV & 306.50 & 0.143 & 0.047 \\
\hline Uzbekistan & Schemes III and M4 & 275.60 & 0.129 & 0.043 \\
\hline Vanuatu & Schemes M4 and III & 17.00 & 0.008 & 0.003 \\
\hline Venezuela & Schemes III and IV & 2659.10 & 1.244 & 0.415 \\
\hline Vietnam & Bretton Woods & 329.10 & 0.154 & 0.214 \\
\hline Yemen, Republic of & Schemes III and M4 & 243.50 & 0.114 & 0.117 \\
\hline Zambia & Schemes III and M4 & 489.10 & 0.229 & 0.022 \\
\hline Zimbabwe & Schemes M4 and M7 & 353.40 & 0.165 & 0.026 \\
\hline
\end{tabular}

Source: Finance Department, International Monetary Fund.

1/ Based on 1992-2004 data. Reflects the impact of adjustments to current receipts and payments for re-exports, international banking interest, and non-monetary gold.

2/ The calculated quota of a member is the higher of the Bretton Woods calculation and the average of the lowest two of the remaining four calculations. 


\section{REFERENCES}

Berg, Andrew, Eduardo Borensztein, Gian Maria Milesi-Ferretti, and Catherine Pattillo, 1999, "Anticipating Balance of Payments Crises: The Role of Early Warning Systems," Occasional Paper No. 186, (Washington, D.C.: International Monetary Fund).

Blinder, Alan, 2003, “A New Global Financial Order: The Art of the Possible,” in D. Das (ed.) An International Finance Reader (London: Routledge), 2003, pp. 104-113 (an update and revision of "Eight Steps to a New Financial Order," Foreign Affairs, September/October 1999).

Boughton, James M., 2001, Silent Revolution: The International Monetary Fund, 1979-1989, (Washington: International Monetary Fund).

Buira, Ariel, 2003, "The Governance of the International Monetary Fund," Challenges to the World Bank and the IMF — Developing Countries Perspectives, Buira, Ariel (ed.).

Caballero, Ricardo, and Arvind Krishnamurthy, 2001, "International and Domestic Collateral Constraints in a model of Emerging Market Crises," Journal of Monetary Economics, 48, pp. 513-548.

Calvo, Guillermo, 1996, “Capital Flows and Macroeconomic Management: Tequilla Lessons," International Journal of Finance and Economics, (July).

, and Carmen Reinhart, 2000, "Fear of Floating," Quarterly Journal of Economics, May, pp. 379-408.

Chang, Roberto, and Andres Velasco, 1998, "Financial Crises in Emerging Markets: A Canonical Model," NBER Working Paper W6606. http://papers.nber.org/papers/W6606.pdf.

,2000, "Financial Fragility and the Exchange Rate Regime," Journal of Economic Theory, XCII, pp. 1-34.

Diamond, Douglas, and Philip Dybvig, 1983, "Bank Runs, Deposit Insurance, and Liquidity," Journal of Political Economy, SCI, pp. 401-419.

dos Reis, Laura, 2005, "Measuring Vulnerability: Capital Flows Volatility in the Quota Formula." Reforming the Governance of the IMF and the World Bank, Buira, Ariel (ed.), pp. 195-212.

Eichengreen, Barry, and Ricardo Hausmann, 1999, "Exchange Rates and Financial Fragility,” NBER Working Paper W7418, http://papers.nber.org/papers/W7418.pdf. 
Feldstein, M., 1998, Refocusing the IMF, in Foreign Affairs, March-April.

Flood, Robert, and Peter Garber, 1984, "Collapsing Exchange-rate Regimes: Some Linear Examples," Journal of International Economics, No. 17, pp. 1-13.

International Monetary Fund, 2000a, External Review of Quota Formulas (EBAP/00/52, 5/1/00, Supplements 1 and 2, 5/1/00 and Supplement 3, 5/2/00) http://www.imf.org/external/np/tre/quota/2000/eng/qfrg/appb/index.htm.

, 2000b, Staff Commentary on the External Review of Quota Formulas (EBAP/00/66, 6/7/00) http://www.imf.org/external/np/tre/quota/2000/eng/qfrg/comment/index.htm .

, 2001a, IMF Executive Board Informally Discusses Quota Formulas, PIN No. 01/118, November 7, 2001, http://www.imf.org/external/np/sec/pn/2001/pn01118.htm.

, 2001b, Alternative Quota Formulas - Considerations, Annex II, (SM/01/293, 9/27/01) http://www.imf.org/external/np/tre/quota/2001/eng/aqfc.htm.

, 2002, Executive Board Discusses Further Considerations in the Twelfth General Review of Quotas, PIN No. 02/105, September 20, 2002 http://www.imf.org/external/np/sec/pn/2002/pn02105.htm.

, 2005, "Quotas and Voice-Further Considerations," SM/05/341, September 2, 2005, p. 29, http://www.imf.org/external/np/pp/eng/2005/090205a.pdf .

Kelkar, L. Vijay, Praveen K. Chaudhry, Marta Vanduzer-Snow, and V. Bhaskar, 2005, "Reforming the International Monetary Fund: Toward Enhanced Accountability and Legitimacy." Reforming the Governance of the IMF and the World Bank, Buira, Ariel (ed.), pp. 45-74.

Kenen, Peter B., 2001, The International Financial Architecture: What's New? What's Missing?, (Washington: Institute for International Economics) http://bookstore.petersoninstitute.org/merchant.mvc?Screen=PROD\&Product_Code= 335.

King, Mervyn, "Reform of the International Monetary Fund," speech given at the Indian Council for Research on International Economic Relations (ICRIER) in New Delhi, India on 20 February 2006. Available at http://www.bankofengland.co.uk/publications/speeches/2006/speech267.pdf.

Krugman, Paul, 1979, “A Model of Balance of Payments Crises," Journal of Money, Credit and Banking, XI, pp. 311-325.

, 1999, "Balance Sheets, the Transfer Problem, and Financial Crises," in International Finance and Financial Crises: Essays in Honor of Robert P. Flood, Jr. (Washington, D.C.: International Monetary Fund). 
Le Fort V, Guillermo, 2005, "Issues on IMF Governance and Representation: An Evaluation of Alternative Options." Reforming the Governance of the IMF and the World Bank, Buira, Ariel (ed.).

Macedo, Stephen, 1998, “The Politics of Justification," Political Theory, v. 18, no. 2 (May, 1990), pp. 280-304. - reprinted in Public Reason, Fred D'Agostino and Gerald F. Gaus, eds., International Research Library of Philosophy (Ashgate Publishing: Aldershot, UK).

McLenaghan, John B., 2005, "Purchasing Power Parities and Comparisons of GDP in IMF Quota Calculations." Reforming the Governance of the IMF and the World Bank, Buira, Ariel (ed.), pp. 171-194.

Mikesell, R., 1994, “The Bretton Woods Debates: a Memoir, Essays in International Finance, Department of Economics, Princeton University, March, no. 192.

Moggridge, Donald (ed.), 1980, The Collected Writings of John Maynard Keynes, Activities 1940-1944, Shaping the Post-War World: The Clearing Union. Volume XXV (Macmillan Cambridge University Press for the Royal Economic Society).

Neiss, Hubert, "Conditionality and Program Ownership" Written Remarks during IMF Seminar on Conditionality, Tokyo, July 10, 2001.

Nozick, Robert, 1974, Anarchy, State, and Utopia, Basic Books, Inc. , 2001, Invariances: The Structure of the Objective World, Cambridge, Massachusetts: Harvard University Press, 2001.

Obstfeld, Maurice, 1994, “The Logic of Currency Crises," Cahiers Economiques et Monétaires, XLIII, pp. 189-213.

, 1996, "Models of Currency Crises with Self-Fulfilling Features," European Economic Review, XL, 1037-1047.

Portugal, Murilo, 2005, "Improving IMF Governance and Increasing the Influence of Developing Countries in IMF Decision-Making." Reforming the Governance of the IMF and the World, Buira, Ariel (ed.), pp. 75-106.

Radelet, Steven and Jeffrey Sachs, 1998, "The Onset of the East Asian Financial Crisis," Chapter 20 in National Bureau of Economic Research, Asian Crisis and International Solutions.

Rawls, John ,1987, “The Idea of an Overlapping Consensus," Oxford Journal of Legal Studies 7 (Spring): pp.1-25. 
, 1988, "The Priority of Right and Ideas of the Good," Philosophy and Public Affairs 17 (Fall): pp. 251-76.

, 1989, "The Domain of the Political and Overlapping Consensus," New York University Law Review 64 (May): pp. 233-55.

, 1996, Political Liberalism, Paperback edition, with new Introduction. (New York: Columbia University Press).

, 1999, A Theory of Justice, revised edition, (Cambridge, Mass.: Harvard University Press).

Truman, Edwin M., 2006, A Strategy for IMF Reform, Policy Analyses in International Economics Number 77, (Washington: Institute for International Economics) http://bookstore.petersoninstitute.org/merchant.mvc?Screen=PROD\&Product_Code= 3985

Van Houtven, Leo, 2002, Governance of the IMF, (Washington DC: International Monetary Fund).

Woods, N., 1998, "Governance in International Organizations: The Case of Reform in the Bretton Woods Institutions," International Monetary and Financial Issues for the 1990, Geneva: UNCTAD, Vol. IX.

,2001, "Making the IMF and the World Bank More Accountable," International Affairs, 77.1.

Yaqub, Muhammad, Azizali Mohammed, and Iqbal Zaidi, 1996, “A Focused SDR Allocation," in Mussa, Michael, James M. Boughton, and Peter Isard, The Future of the SDR in Light of Changes in the International Financial System, (Washington DC: International Monetary Fund), pp. 202-216. 